\title{
Comparison of free and bound phenolic compositions and antioxidant activities of leaves from different mulberry varieties
}

\author{
Zhenjiang Wang ${ }^{1,2}$, Cuiming Tang ${ }^{1,2}$, Gengsheng Xiao ${ }^{1}$, Fanwei Dai ${ }^{1,2}$, Sen Lin ${ }^{1}$, Zhiyi Li ${ }^{1}$ and Guoging Luo ${ }^{1 *}$
}

\begin{abstract}
Mulberry leaves are used in traditional Chinese medicine and contain numerous active substances that are known to be beneficial for human health. The aim of this study was to investigate the phenolic compositions and antioxidant activities of the leaves from 23 mulberry cultivars. Qualitative LC-ESI-QTOF analysis revealed the presence of 11 phenolic compounds in the free phenolic extracts and 10 phenolic compounds in the bound fractions. Chlorogenic acid and caffeic acid were the major components in the free and bound fractions, respectively. The results revealed that the changguosang cultivar from Taiwan contained the greatest content of phenolic compounds as well as the highest antioxidant activity among the 23 cultivars examined, as determined using three separate antioxidant assays. The isoquercitrin, chlorogenic acid, and rutin contents of the free phenolic extracts displayed significant correlations with the antioxidant activities, while syringic acid and rutin were the main contributors to the antioxidant activities of the bound phenolic fractions. The obtained results demonstrate that mulberry leaves contain a variety of beneficial phenolic substances and may be suitable for further development as a herbal medicine.
\end{abstract}

Keywords: Bound Phenolics, Antioxidant properties, Mulberry leaf, Free Phenolics, Mulberry variety

\section{Introduction}

Phytonutrients play important roles in improving human health and may protect against heart disease, cancer, the effects of aging, and membrane damage. In particular, phytonutrients possessing antioxidant properties can inhibit the propagation of free-radical reactions implicated in the development of aging-related diseases. Consequently, numerous studies have been conducted to elucidate the characteristics and roles of antioxidant compounds from plants. Antioxidants can delay or suppress the oxidation of molecules by inhibiting the activation or propagation of oxidative chain reactions or scavenging the free radicals generated during oxidative

\footnotetext{
*Correspondence: guo_qingl@sina.com

1 Sericulture \& Agri-Food Research Institute, Guangdong Academy

of Agricultural Sciences, Guangzhou, China

Full list of author information is available at the end of the article
}

processes [37]. The antioxidant activity of plant tissues is primarily attributable to phenolic, etc. and a high correlation was observed between the antioxidant activity and the total phenolic content of the extract. [1]. Hence, phenolic compounds have attracted considerable attention as potential protective factors against cancer and heart disease owing to their antioxidant activities [8].

Mulberry (Morus alba L.) is a moraceous plant that is extensively cultivated throughout Asia to feed silkworms during the commercial production of silk. It is distributed throughout temperate to subtropical and tropical regions and can be grown under a wide range of climatic, topographic, and soil conditions [11]. Mulberry leaves are considered a nutritious, palatable, and safe food or food additive containing carbohydrates, proteins, calcium, iron, $\beta$-carotene, and vitamin B1 [6] and are also a rich source of phenolic compounds such as caffeic acid, rutin, quercetin, isoquercitrin, and astragalin [9, 
23]. Mulberry leaves are commonly used as antidiabetic, hypolipidemic, antihypertensive, anti-atherosclerotic, and anticonvulsant agents [4]. These pharmacological effects of mulberry leaves are closely related to their phenolic composition [14]. Plant phenolic compounds have been reported to play a preventive role against various diseases owing to their remarkable antioxidant, antimicrobial, and other activities [7, 29]. For example, Wu et al. [38] reported that mulberry leaf phenolic extract decreases hepatic lipid accumulation via activation of the AMP-activated protein kinase signaling pathway.

There is strong evidence for the variation of phenolic content and antioxidant activity among different species of plants belonging to the same genus [30,35]. Thus, the identification and quantification of phenolic compounds can provide crucial information regarding the antioxidant function, food quality, and potential health benefits of a specific plant. G1, G6, G8, and GSW are from North China; B-2-8, R2, 7403, and DS are from South China; $\mathrm{Z1}, \mathrm{Z} 2$, and Z4 are from Southwest China; CGS is from Taiwan; J4-1 and J5 are from Japan; T6, T7, BR60, S54, and $\mathrm{QM}$ are from Thailand; Y2 and YXM2 are from India; and Y1 and YD are from Vietnam. Therefore, the aim of this study was to determine and compare the phenolic compositions and antioxidant activities of these 23 samples of mulberry leaves.

\section{Materials and methods}

\section{Mulberry leaf samples and preparation}

All of the mulberry varieties examined in this study were cultivated in an experimental field in Guangzhou, which was managed by the South China branch of the National Mulberry Germplasm Resource Garden. Mulberry leaves are generally picked in the spring and late autumn frost period, and it is better to pick them in the morning and evening. Leaves from each mulberry variety were harvested, washed with distilled water, and air-dried at $55{ }^{\circ} \mathrm{C}$ in a thermostatic hot air drying oven for 7-9 h. The dried leaves were ground into powders using a high-speed pulverizer and stored in airtight containers at $-20^{\circ} \mathrm{C}$ prior to analysis [35]. The different mulberry varieties examined are listed in Table 1.

\section{Chemicals and reagents}

Acetone, $n$-hexane, ethyl acetate, concentrated sulfuric acid, sodium hydroxide, phosphoric acid, acetonitrile, ascorbic acid, methanol, formic acid, sodium acetate, acetic acid, hydrochloric acid, iron(III) chloride hexahydrate solution, ammonium acetate, were purchased from Guangzhou Chemical Reagent Factory (Guangzhou, China). phenolic compound standards [rutin (Rut), quercetin (Que), quercitrin (Quer), isoquercitrin (Iso), chlorogenic acid (ChA), syringic acid (SyA), ferulic acid
Table 1 Names, species, and abbreviations of the mulberry varieties examined in this study

\begin{tabular}{lll}
\hline Cultivar & Species & Abbreviation \\
\hline Gu 1 & M. alba L & G1 \\
Gu 6 & M. alba L & G6 \\
Gu 8 & M. alba L & G8 \\
Gusangwang & M. mongolica var. diabolica Koidz & GSW \\
Bei-2-8 & M. atropurpurea Roxb & B-2-8 \\
R2 & M. atropurpurea Roxb & R2 \\
7403 & M. atropurpurea Roxb & 7403 \\
Dashi & M. atropurpurea Roxb & DS \\
Zangjiangxin 1 & M. mongolica C.K.Schneid & Z1 \\
Zangjiangxin 2 & M. mongolica C.K.Schneid & Z2 \\
Zangjiangxin 4 & M. mongolica C.K.Schneid & Z4 \\
Changguosang & M. rotundiloba Koidz & CGS \\
JP4-1 & M. multicaulis Koidz & J4-1 \\
JP5 & M. multicaulis Koidz & J5 \\
TL6 & M. rotundiloba Koidz & T6 \\
TL7 & M. rotundiloba Koidz & T7 \\
BR60 & M. rotundiloba Koidz & BR60 \\
S54 & M. rotundiloba Koidz & S54 \\
Qingmai & M. rotundiloba Koidz & QM \\
Yin 2 & M. serrata Rox & Y2 \\
Yinximeng 2 & M. serrata Rox & YXM2 \\
Yue 1 & M. rotundiloba Koidz & Y1 \\
Yueda & Motundiloba Koidz & YD \\
\hline & &
\end{tabular}

(FeA), caffeic acid (CaA), resveratrol (Res), epicatechin (Epi), astragalin (Ast), scopoletin (Sco), galangal (Gal), catechuic acid (CatA), vanillic acid (VaA), benzoic acid $(\mathrm{BeA})$, gallic acid $(\mathrm{GaA})$, and protocatechuic acid $(\operatorname{PrA})]$ were purchased from the National Institutes for Food and Drug Control (Beijing, China). 2,4,6-tris(2-pyridyl)-S-triazine (TPTZ), 1,1-diphenyl-2-picrylhydrazyl (DPPH), 2,2'-Azino-bis(3-ethylbenzothiazoline-6-sulfonic acid) diammonium salt (ABTS), and 6-hydroxy-2,5,7,8-tetramethylchroman-2-carboxylic acid (trolox) were purchased from Sigma-Aldrich (St. Louis, MO, USA).

\section{Extraction of free phenolic compounds}

It was necessary to remove lipids from the mulberry leaves prior to extraction of the free phenolic compounds [12]. Considering that the lipid content of mulberry leaves is not high, the degreasing procedure in this study was adjusted. Free phenolic compounds were extracted according to a modified version of the methods reported by Li et al. [20] and Kim et al. [16]. Briefly, samples of the dried leaves $(10 \mathrm{~g})$ were extracted with $n$-hexane $(250 \mathrm{~mL})$ for $10 \mathrm{~min}$ under continuous stirring $(10,000 \mathrm{rpm})$ in an ice bath, followed by centrifugation (5000 rpm, $5 \mathrm{~min}$ ) and removal of the supernatant. 
The residue was added to chilled acetone/water (8:2, $\mathrm{v} / \mathrm{v}, 250 \mathrm{~mL}$ ) followed by homogenization $(5000 \mathrm{rpm}$, $5 \mathrm{~min}$ ) and centrifugation (5000 rpm, $5 \mathrm{~min}$ ). The residue was extracted again under the same conditions. The two supernatants were combined and evaporated to dryness at $50{ }^{\circ} \mathrm{C}$ on a rotary evaporator (RE-52AA, Shanghai Yarong Biochemical instrument Factory, Shanghai, China). The dried samples were dissolved in methanol/ water $(8: 2, \mathrm{v} / \mathrm{v})$, filtered through $0.22 \mu \mathrm{m}$ membrane filters, and stored at $-80{ }^{\circ} \mathrm{C}$ prior to analysis. Each sample was extracted in duplicate. The residue was used to measure the bound phenolic compounds, as described in the following subsection.

\section{Extraction of bound phenolic compounds}

The bound phenolic compounds were extracted by alkaline hydrolysis according to previously described procedures $[5,18,21]$ with some modifications. Briefly, the mulberry leaf residues obtained after extraction of the free phenolic compounds were hydrolyzed in $2 \mathrm{M}$ $\mathrm{NaOH}(100 \mathrm{~mL})$ at room temperature for $1.5 \mathrm{~h}$ with continuous stirring under nitrogen atmosphere. The resulting mixtures were acidified to $\mathrm{pH} 2$ with $6 \mathrm{M} \mathrm{HCl}$ and then extracted six times with ethyl acetate $(120 \mathrm{~mL}$ each time). The ethyl acetate fractions were combined and evaporated to dryness at $45{ }^{\circ} \mathrm{C}$ on a rotary evaporator (RE-52AA). The dried extracts were redissolved in $80 \%$ methanol, filtered through $0.22 \mu \mathrm{m}$ membrane filters, and stored at $-80^{\circ} \mathrm{C}$ prior to analysis.

\section{LC-ESI-QTOF analysis}

Samples were analyzed by LC-ESI-QTOF according to a modified version of the method described by Tomas et al. [36]. Each sample was vortexed for $30 \mathrm{~s}$, filtered through a $0.22 \mu \mathrm{m}$ organic membrane, and transferred into an injection vial. The temperature of the chromatographic column was set to $35{ }^{\circ} \mathrm{C}$, and the injection volume was $1 \mu \mathrm{L}$. The mobile phase consisted of $0.1 \%$ formic acid in water (solvent $\mathrm{A}$ ) and $0.1 \%$ formic acid in acetonitrile (solvent $\mathrm{B}$ ) in positive ion mode or $2 \mathrm{mM}$ ammonium acetate in water (solvent A) and acetonitrile (solvent B) in negative ion mode. The flow rate was set to $400 \mu \mathrm{L} /$ min with a gradient from 5 to $95 \%$ solvent B over 22 min, as shown in Table 2. The Agilent 6545A QTOF mass spectrometer is controlled by the control software (LC/ MS Data Acquisition, Version B.08.00) based on the Auto MS/MS mode for primary and secondary mass spectrometry data acquisition. The MS and MS2 acquisition rates were 5 and 10 spectra per second, respectively. The secondary collision energy is $0 \mathrm{v}$ and $10 \mathrm{v}$ respectively. Eight ions were selected in the first-level spectrum for the second-level scan. The $\mathrm{m} / \mathrm{z}$ range of primary and secondary mass scanning are both 50-1100. Spectra were
Table 2 LC-ESI-QTOF mobile phase gradient

\begin{tabular}{llll}
\hline Time $(\mathrm{min})$ & Flow rate $(\mu \mathrm{L} / \mathrm{min})$ & $\mathrm{A}(\%)$ & $\mathrm{B}(\%)$ \\
\hline 0 & 400 & 95 & 5 \\
1.5 & 400 & 95 & 5 \\
2.5 & 400 & 90 & 10 \\
14 & 400 & 60 & 40 \\
22 & 400 & 5 & 95 \\
25 & 400 & 5 & 95 \\
26 & 400 & 95 & 5 \\
30 & 400 & 95 & 5 \\
\hline
\end{tabular}

collected in both positive and negative modes, and the acquired data were saved in centroid format. The ESI ion source parameters were as follows: ion source gas temperature, $320^{\circ} \mathrm{C}$; nitrogen flow rate, $8 \mathrm{~L} / \mathrm{min}$; sheath gas flow rate, $12 \mathrm{~L} / \mathrm{min}$; sheath gas temperature, $350{ }^{\circ} \mathrm{C}$; capillary voltage, $4000 \mathrm{~V}$ (positive ion mode) or $3500 \mathrm{~V}$ (negative ion mode).

\section{Determination of phenolic content using HPLC}

The phenolic compounds present in the 23 mulberry leaf samples were determined by HPLC analysis (Agilent 1200, Agilent Technologies Inc., Karlsruhe, Germany) according to a modified version of the methods reported by Eom et al. [10] and Subhashinee et al. [33]. Chromatographic separation was performed using an Capcell Pak ADME column $(250 \times 4.6 \mathrm{~mm}, 5 \mu \mathrm{m})$. The mobile phase consisted of phosphoric acid/water $(0.2: 100, \mathrm{v} / \mathrm{v}$, solvent $\mathrm{A}$ ) and acetonitrile (solvent $\mathrm{B}$ ). The solvent gradient was as follows: $0-20 \mathrm{~min} 10 \% \mathrm{~B}, 20-30 \mathrm{~min} 16 \% \mathrm{~B}$, $30-40$ min $16 \%$ B, $40-60 \min 20 \%$ B, $60-70 \min 30 \%$ B, $70-71 \min 35 \%$ B, $71-75 \min 80 \%$ B, $75-76 \min 80 \%$ B, $76-90 \mathrm{~min} 10 \% \mathrm{~B}$. The solvent flow rate was $1.0 \mathrm{~mL} / \mathrm{min}$, the column temperature was set to $25^{\circ} \mathrm{C}$, and chromatograms were recorded at $280 \mathrm{~nm}$ and $350 \mathrm{~nm}$.

Dionex Acclaim 120 C-18 analytical column.

CAPCELL PAK ADM.

\section{Determination of FRAP activity}

The ferric reducing antioxidant power (FRAP) assay was performed according to a modified version of a previously reported method $[39,40]$. A working solution was prepared by mixing $10 \mathrm{~mL}$ of $300 \mathrm{mM}$ acetate buffer $(0.1870 \mathrm{~g}$ of sodium acetate and $1.6 \mathrm{~mL}$ of acetic acid $)$, $1 \mathrm{~mL}$ of TPTZ solution (10 mM TPTZ in $40 \mathrm{mM} \mathrm{HCl})$, and $1 \mathrm{~mL}$ of $20 \mathrm{mM}$ iron(III) chloride hexahydrate solution. This mixture was pre-warmed to $37^{\circ} \mathrm{C}$ and should always be prepared fresh. Samples of the mulberry leaf extracts $(100 \mu \mathrm{L})$ were incubated with $3.0 \mathrm{~mL}$ of the FRAP reagent for $4 \mathrm{~min}$ at $25{ }^{\circ} \mathrm{C}$. The absorbance at 
$593 \mathrm{~nm}$ was then measured using a spectrophotometer (UV-1700, Shimadzu Instruments Manufacturing, CO., LTD, Suzhou, China). The FRAP values were expressed as $\mu \mathrm{mol} \mathrm{Fe}^{2+}$ equivalents per gram of dry weight $(\mu \mathrm{mol}$ $\left.\mathrm{Fe}^{2+} / \mathrm{g} \mathrm{DW}\right)$.

\section{Determination of DPPH radical scavenging activity}

The DPPH radical scavenging activities of the mulberry leaf samples were determined as described in previous reports [2, 3, 22]. Briefly, the mulberry leaf extracts and DPPH solutions were diluted to appropriate concentrations, and a solution of ascorbic acid in methanol was used to prepare a standard curve $\left(R^{2}=0.993\right)$. Next, $1 \mathrm{~mL}$ of the diluted sample was mixed with $5 \mathrm{~mL}$ of $2 \mathrm{mM}$ DPPH solution in methanol. The mixture was stirred vigorously and incubated for $50 \mathrm{~min}$ in the dark at room temperature. The absorbance at $520 \mathrm{~nm}$ was then measured using a UV2300II spectrophotometer and the results were expressed in $\mu \mathrm{mol}$ of ascorbic acid equivalent antioxidant capacity (AEAC) per gram of dry weight ( $\mu$ mol AEAC/g DW).

\section{Determination of ABTS radical scavenging activity}

The ABTS radical scavenging activities of the mulberry leaf samples were determined as described in previous reports [27, 31, 34]. Briefly, an ABTS stock solution was prepared by mixing $7 \mathrm{mM}$ ABTS and $2.45 \mathrm{mM}$ potassium persulfate $(1: 1, \mathrm{v} / \mathrm{v})$ followed by incubation for $16 \mathrm{~h}$ in the dark at room temperature; the resulting ABTS radical solution was used within $24 \mathrm{~h}$. The ABTS stock solution was diluted with methanol until its absorbance at $734 \mathrm{~nm}$ reached $0.70 \pm 0.02$. Next, $100 \mu \mathrm{L}$ of the diluted sample was mixed with $3.8 \mathrm{~mL}$ of the ABTS working solution and the absorbance at $734 \mathrm{~nm}$ was measured after incubation at room temperature for exactly $6 \mathrm{~min}$. Trolox was used as a reference to generate a standard curve $\left(R^{2}=0.995\right)$, and the results were expressed as $\mu \mathrm{mol}$ of trolox equivalent antioxidant capacity (TEAC) per gram of dry weight ( $\mu$ mol TEAC/g DW).

\section{Results and discussion}

Qualitative analysis of phenolic compounds in mulberry leaves

To determine the presence of various biologically active phenolic compounds in the mulberry leaf samples, the obtained mass spectra of the samples were compared with spectra of standard compounds with respect to retention time (RT), molecular ion peak, and structural fragments observed in the secondary mass spectra.

In LC-MS, a sample is first subjected to liquid chromatography to separate the sample components, which are subsequently ionized and separated according to their mass-to-charge ratios to reveal information regarding the molecular weight, structure, and component amount.

Mulberry leaves are rich in a variety of phenolic compounds, the composition and content of which can vary for mulberry leaves from different cultivars and regions. LC-ESI-QTOF analysis revealed the presence of 11 highly matched phenolic substances in the free phenolic extracts and 10 phenolic substances in the bound phenolic extracts, as summarized in Tables 3 and 4, respectively. The free phenolic compounds detected in the mulberry leaf samples were BeA, PrA, GaA, CaA, Sco, Epi, Que, ChA, Iso, Rut, and Ast, while the bound phenolic compounds were SyA, GaA, BeA, PrA, CaA, Iso, Rut, FeA, Ast, and Que. Among these compounds, Sco, Epi, and ChA were only detected in the free phenolic extracts, which indicates that these substances may be either absent from the bound phenolic extracts. In contrast, SyA and FeA were only detected in the bound

Table 3 Qualitative analysis of free phenolic compounds in mulberry leaves

\begin{tabular}{|c|c|c|c|c|c|c|}
\hline Compound & Molecular formula & Expected $m / z$ & Observed $\mathrm{m} / \mathrm{z}$ & Mass error (ppm) & $\mathrm{RT}(\min )$ & Fragment ions (relative intensity, \%) \\
\hline $\mathrm{BeA}$ & $\mathrm{C}_{7} \mathrm{H}_{6} \mathrm{O}_{2}$ & 121.0295 & 121.0294 & -0.83 & 7.3186 & 121.02985 (100\%), 77.04045 (14.2\%), 82.49994 (1.9\%) \\
\hline $\operatorname{PrA}$ & $\mathrm{C}_{7} \mathrm{H}_{6} \mathrm{O}_{4}$ & 153.0193 & 153.0194 & 0.65 & 7.9276 & 153.01923 (100\%), 153.04488 (3.3\%), 109.02855 (2.6\%) \\
\hline GaA & $\mathrm{C}_{7} \mathrm{H}_{6} \mathrm{O}_{5}$ & 169.0142 & 169.0145 & 1.77 & 3.4645 & 169.01408 (100\%), 125.02387 (3.3\%), 61.7975 (2.5\%) \\
\hline CaA & $\mathrm{C}_{9} \mathrm{H}_{8} \mathrm{O}_{4}$ & 179.0350 & 179.0351 & 0.56 & 7.6609 & $179.03479(100 \%), 135.04578(5.3 \%)$ \\
\hline Sco & $\mathrm{C}_{10} \mathrm{H}_{8} \mathrm{O}_{4}$ & 191.0350 & 191.0350 & 0 & 9.9880 & 191.03455 (100\%), 176.01178 (9.3\%), 147.02908 (3.5\%) \\
\hline Epi & $\mathrm{C}_{15} \mathrm{H}_{14} \mathrm{O}_{6}$ & 289.0718 & 289.0678 & -13.84 & 2.2628 & 243.0616 (100\%), 289.06708 (41.6\%), 244.06404 (12.5\%) \\
\hline Que & $\mathrm{C}_{15} \mathrm{H}_{10} \mathrm{O}_{7}$ & 301.0354 & 301.0356 & 0.66 & 13.8163 & $\begin{array}{l}301.03537(100 \%), 178.99699(6.5 \%), 151.00305(4.4 \%), \\
\quad 63.02433(2.1 \%)\end{array}$ \\
\hline ChA & $\mathrm{C}_{16} \mathrm{H}_{18} \mathrm{O}_{9}$ & 353.0878 & 353.0865 & -3.8 & 6.7420 & 191.05605 (100\%), $192.05885(8.7 \%)$ \\
\hline Iso & $\mathrm{C}_{21} \mathrm{H}_{20} \mathrm{O}_{12}$ & 463.0882 & 463.0903 & 4.53 & 8.6035 & $463.08832(100 \%), 301.03555(3 \%)$ \\
\hline Rut & $\mathrm{C}_{27} \mathrm{H}_{30} \mathrm{O}_{16}$ & 609.1461 & 609.1478 & 2.79 & 8.9101 & 609.14642 (100\%), 609.18945 (9\%), 300.02475 (2.2\%) \\
\hline Ast & $\mathrm{C}_{21} \mathrm{H}_{20} \mathrm{O}_{11}$ & 447.0933 & 447.0942 & -2.01 & 10.6400 & 447.0932 (100\%), 285.0388 (18.98\%), 449.0994 (8.2\%) \\
\hline
\end{tabular}

All spectra were recorded in negative ion mode with a collision energy of $10 \mathrm{~V}$ 
Table 4 Qualitative analysis of bound phenolic compounds in mulberry leaves

\begin{tabular}{|c|c|c|c|c|c|c|}
\hline Compound & Molecular formula & Expected $\mathrm{m} / \mathrm{z}$ & Observed $\mathrm{m} / \mathrm{z}$ & Mass error (ppm) & $\mathrm{RT}(\min )$ & Fragment ions (relative intensity, \%) \\
\hline SyA & $\mathrm{C}_{9} \mathrm{H}_{10} \mathrm{O}_{5}$ & 197.0455 & 197.0457 & 1.01 & 3.3027 & $\begin{array}{l}135.04504(100 \%), 153.05786(31.6 \%), 162.83853(26.5 \%) \\
\quad 61.98833(25.3 \%)\end{array}$ \\
\hline $\mathrm{GaA}$ & $\mathrm{C}_{7} \mathrm{H}_{6} \mathrm{O}_{5}$ & 169.0142 & 169.0144 & 1.18 & 3.4643 & $\begin{array}{l}169.01404(100 \%), 168.88683(15.4 \%), 125.02482(8.8 \%), \\
122.89381(2.7 \%)\end{array}$ \\
\hline $\mathrm{BeA}$ & $\mathrm{C}_{7} \mathrm{H}_{6} \mathrm{O}_{2}$ & 121.0295 & 121.0305 & 8.26 & 7.3001 & $121.02959(100 \%), 77.04009(10.4 \%), 77.05341(0.8 \%)$ \\
\hline PrA & $\mathrm{C}_{7} \mathrm{H}_{6} \mathrm{O}_{4}$ & 153.0193 & 153.0193 & 0 & 7.7071 & 153.01918 (100\%), $109.02876(6.1 \%)$ \\
\hline $\mathrm{CaA}$ & $\mathrm{C}_{9} \mathrm{H}_{8} \mathrm{O}_{4}$ & 179.0350 & 179.0352 & 1.12 & 7.7366 & $179.03502(100 \%), 135.04532(12.9 \%)$ \\
\hline Iso & $\mathrm{C}_{21} \mathrm{H}_{20} \mathrm{O}_{12}$ & 463.0882 & 463.0877 & -1.08 & 8.5514 & $463.08813(100 \%), 301.03839(3.6 \%), 193.01373(1.9 \%)$ \\
\hline Rut & $\mathrm{C}_{27} \mathrm{H}_{30} \mathrm{O}_{16}$ & 609.1461 & 609.1469 & 1.31 & 9.2957 & $609.14612(100 \%), 300.02649$ (3.7\%) \\
\hline FeA & $\mathrm{C}_{10} \mathrm{H}_{10} \mathrm{O}_{4}$ & 193.0506 & 193.0508 & 1.04 & 10.0027 & 193.05028 (100\%), $134.03656(4.7 \%)$ \\
\hline Ast & $\mathrm{C}_{21} \mathrm{H}_{20} \mathrm{O}_{11}$ & 447.0933 & 447.0937 & 0.89 & 10.9455 & 447.0921 (100\%), $285.03876(3.7 \%)$ \\
\hline Que & $\mathrm{C}_{15} \mathrm{H}_{10} \mathrm{O}_{7}$ & 301.0354 & 301.0353 & -0.33 & 13.7901 & 301.03534 (100\%), 300.99191 (5.2\%) \\
\hline
\end{tabular}

All spectra were recorded in negative ion mode with a collision energy of $10 \mathrm{~V}$

phenolic extracts and not in the free phenolic extracts. Zou et al. [40] reported certain differences in the phenolic contents of different varieties of mulberry leaves, which is useful for helping farmers to select which varieties to cultivate for higher quality mulberry leaves. Qadir et al. [26] applied gas chromatography-mass spectrometry to identify and quantify the main phenolic compounds present in $M$. alba leaf extracts, including Que, $\mathrm{GaA}$, and SyA. In the bound phenolic extracts, ChA was not detected, indicating that ChA may only exist in the free phenolic extracts. Most of the phenolic substances present in high contents in the free and bound phenolic extracts could be qualitatively analyzed by LC-MS.

\section{Total phenolic contents}

The total phenolic contents in the $80 \%$ acetone extracts of the 23 samples were measured by HPLC as presented in Table 5 and Fig. 1, revealing clear differences between the various cultivars. The total phenolic contents (including both free and bound compounds) increased in the following order: G1 $(2.61 \mathrm{mg} / \mathrm{g} \mathrm{DW})<\mathrm{S} 54$ $(4.0 \mathrm{mg} / \mathrm{g} \mathrm{DW})<\mathrm{G} 8(4.22 \mathrm{mg} / \mathrm{g} \mathrm{DW})<\mathrm{BR} 60(4.55 \mathrm{mg} / \mathrm{g}$ $\mathrm{DW})<7403(4.62 \mathrm{mg} / \mathrm{g} \mathrm{DW})<\mathrm{Z} 1 \quad(4.97 \mathrm{mg} / \mathrm{g} \mathrm{DW})<\mathrm{Z} 2$ $(5.98 \mathrm{mg} / \mathrm{g} \mathrm{DW})<\mathrm{J} 5(7.08 \mathrm{mg} / \mathrm{g} \quad \mathrm{DW})<\mathrm{G} 6(7.47 \mathrm{mg} / \mathrm{g}$ DW $)<$ Z4 $(7.50 \mathrm{mg} / \mathrm{g}$ DW $)<$ T7 $(8.07 \mathrm{mg} / \mathrm{g}$ DW $)<$ YXM2 $(8.24 \mathrm{mg} / \mathrm{g} \mathrm{DW})<\mathrm{R} 2(9.66 \mathrm{mg} / \mathrm{g} \mathrm{DW})<\mathrm{T} 6(13.49 \mathrm{mg} / \mathrm{g}$ DW $)<$ B-2-8 $\quad(16.27 \quad \mathrm{mg} / \mathrm{g} \quad \mathrm{DW})<\mathrm{QM} \quad(16.75 \quad \mathrm{mg} / \mathrm{g}$ $\mathrm{DW})<\mathrm{GSW} \quad(17.3 \quad \mathrm{mg} / \mathrm{g} \quad \mathrm{DW})<\mathrm{J4}-1 \quad(18.46 \quad \mathrm{mg} / \mathrm{g}$ DW $)<\mathrm{Y} 2(23.83 \mathrm{mg} / \mathrm{g}$ DW $)<\mathrm{YD}(25.72 \mathrm{mg} / \mathrm{g} \mathrm{DW})<\mathrm{DS}$ $(27.99 \mathrm{mg} / \mathrm{g} \quad \mathrm{DW})<\mathrm{Y} 1 \quad(39.12 \quad \mathrm{mg} / \mathrm{g} \quad \mathrm{DW})<\mathrm{CGS}$ (51.81 mg/g DW).

Table 5 also lists the free and bound phenolic contents and their corresponding percentages for the 23 samples. The contribution of the free phenolic fraction to the total phenolic content ranged from $85.39 \%$ ( $\mathrm{Z} 2$ ) to $98.97 \%$ (CGS). The free phenolic content in the 23 varieties of mulberry leaves varied from $2.26 \mathrm{mg} / \mathrm{g} \mathrm{DW}$ (G1) to $51.28 \mathrm{mg} / \mathrm{g}$ DW (CGS) and followed almost the same order as the total phenolic content: G1 $(2.26 \mathrm{mg} / \mathrm{g}$ DW $)<$ S54 $(3.69 \mathrm{mg} / \mathrm{g}$ DW $)<$ G8 $(4.02 \mathrm{mg} / \mathrm{g} \mathrm{DW})<$ BR60 $(4.3 \mathrm{mg} / \mathrm{g} \mathrm{DW})<7403(4.35 \mathrm{mg} / \mathrm{g} \mathrm{DW})<\mathrm{Z} 1(4.53 \mathrm{mg} / \mathrm{g}$ $\mathrm{DW})<\mathrm{Z} 2(5.11 \mathrm{mg} / \mathrm{g} \quad \mathrm{DW})<\mathrm{Z} 4 \quad(6.75 \mathrm{mg} / \mathrm{g} \quad \mathrm{DW})<\mathrm{J} 5$ $(6.80 \mathrm{mg} / \mathrm{g} \mathrm{DW})<\mathrm{G} 6(7.15 \mathrm{mg} / \mathrm{g} \mathrm{DW})<\mathrm{T} 7(7.83 \mathrm{mg} / \mathrm{g}$ DW $)<$ YXM2 $\quad(7.85 \quad \mathrm{mg} / \mathrm{g} \quad$ DW $)<\mathrm{R} 2 \quad(9.32 \quad \mathrm{mg} / \mathrm{g}$ DW $)<\mathrm{T} 6 \quad(12.95 \quad \mathrm{mg} / \mathrm{g} \quad \mathrm{DW})<\mathrm{B}-2-8 \quad(15.76 \quad \mathrm{mg} / \mathrm{g}$ DW $)<$ GSW $\quad(16.19 \quad \mathrm{mg} / \mathrm{g} \quad \mathrm{DW})<\mathrm{QM} \quad(16.24 \quad \mathrm{mg} / \mathrm{g}$ DW $)<\mathrm{J} 4-1 \quad(17.71 \quad \mathrm{mg} / \mathrm{g} \quad \mathrm{DW})<\mathrm{Y} 2 \quad(23.13 \quad \mathrm{mg} / \mathrm{g}$ DW $)<\mathrm{YD}(25.35 \mathrm{mg} / \mathrm{g}$ DW $)<\mathrm{DS}(27.16 \mathrm{mg} / \mathrm{g} \mathrm{DW})<\mathrm{Y} 1$ $(38.48 \mathrm{mg} / \mathrm{g} \mathrm{DW})<$ CGS (51.28 mg/g DW).

In contrast, the bound phenolic content in the samples followed a quite different order: G8 $(0.20 \mathrm{mg} / \mathrm{g} \mathrm{DW})<\mathrm{T} 7$

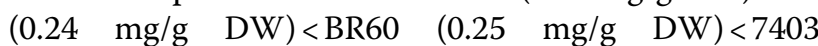
$(0.27 \mathrm{mg} / \mathrm{g} \mathrm{DW})<J 5(0.29 \mathrm{mg} / \mathrm{g} \mathrm{DW})<$ S5 $4(0.31 \mathrm{mg} / \mathrm{g}$ $\mathrm{DW})<\mathrm{G} 6 \quad(0.33 \mathrm{mg} / \mathrm{g} \quad \mathrm{DW})<\mathrm{R} 2$ and $\mathrm{G} 1 \quad(0.34 \mathrm{mg} / \mathrm{g}$ $\mathrm{DW})<\mathrm{YD}(0.37 \mathrm{mg} / \mathrm{g} \mathrm{DW})<\mathrm{YXM} 2(0.39 \mathrm{mg} / \mathrm{g} \mathrm{DW})<\mathrm{Z} 1$ $(0.44 \quad \mathrm{mg} / \mathrm{g} \quad \mathrm{DW})<\mathrm{QM} \quad(0.51 \quad \mathrm{mg} / \mathrm{g} \quad \mathrm{DW})<\mathrm{B}-2-8$ $(0.51 \mathrm{mg} / \mathrm{g} \mathrm{DW})<\mathrm{CGS}(0.53 \mathrm{mg} / \mathrm{g} \mathrm{DW})<\mathrm{T} 6(0.54 \mathrm{mg} / \mathrm{g}$ $\mathrm{DW})<\mathrm{Y} 1(0.64 \mathrm{mg} / \mathrm{g} \mathrm{DW})<\mathrm{Y} 2(0.71 \mathrm{mg} / \mathrm{g} \quad \mathrm{DW})<\mathrm{J} 4-1$ $(0.75 \mathrm{mg} / \mathrm{g} \mathrm{DW})<\mathrm{Z} 4(0.75 \mathrm{mg} / \mathrm{g}$ DW $)<\mathrm{DS}(0.83 \mathrm{mg} / \mathrm{g}$ DW $)<$ Z2 $(0.87 \mathrm{mg} / \mathrm{g} \mathrm{DW})<$ GSW $(1.11 \mathrm{mg} / \mathrm{g} \mathrm{DW})$.

Overall, the results revealed that CGS from Taiwan possessed the highest total and free phenolic contents, whereas G1 from North China displayed the lowest values among the 23 cultivars studied. In contrast, the bound phenolic contents of the mulberry cultivars followed a different trend, with the highest and lowest values observed for GSW and G8, respectively. The results further demonstrate that the phenolic compounds present in mulberry leaves predominantly exist in the free state. Furthermore, the total phenolic contents of 
Table 5 Total, free, and bound phenolic contents of the 23 mulberry leaf samples

\begin{tabular}{|c|c|c|c|}
\hline Cultivar & $\begin{array}{l}\text { Total phenolic content } \\
(\mu \mathrm{g} / \mathrm{g} \text { DW) }\end{array}$ & $\begin{array}{l}\text { Free phenolic content } \\
(\mu \mathrm{g} / \mathrm{g} D W)\end{array}$ & $\begin{array}{l}\text { Bound phenolic content } \\
\text { ( } \mu \mathrm{g} / \mathrm{g} D W)\end{array}$ \\
\hline G1 & $2607.7 \pm 161.35^{k}$ & $2264.56 \pm 161.35^{k}(86.84 \%)$ & $343.14 \pm 46.25^{\text {ghi }}(13.16 \%)$ \\
\hline G6 & $7472.27 \pm 572.98^{\text {hij }}$ & $7147.13 \pm 572.98^{\mathrm{ijk}}(95.65 \%)$ & $325.14 \pm 43.63^{\text {ghi }}(4.35 \%)$ \\
\hline G8 & $4224.72 \pm 418.4^{\mathrm{jjk}}$ & $4023.23 \pm 418.4^{\mathrm{ijk}}(95.23 \%)$ & $201.49 \pm 33.66^{j}(4.77 \%)$ \\
\hline GSW & $17,302.22 \pm 1667.62^{\mathrm{ef}}$ & $16,191.26 \pm 1667.62^{\mathrm{ef}}(93.58 \%)$ & $1110.96 \pm 105.93^{\mathrm{a}}(6.42 \%)$ \\
\hline DS & $27,990.69 \pm 2711.73^{c}$ & $27,156.6 \pm 2711.73^{c}(97.02 \%)$ & $834.08 \pm 80.98 b^{c}(2.98 \%)$ \\
\hline 7403 & $4621.51 \pm 367.57^{\mathrm{ijk}}$ & $4347.98 \pm 367.57^{\mathrm{jik}}(94.08 \%)$ & $273.53 \pm 40.51^{\text {hij }}(5.92 \%)$ \\
\hline $\mathrm{R} 2$ & $9660.23 \pm 831.38^{g h}$ & $9322.52 \pm 831.38^{g h}(96.5 \%)$ & $337.71 \pm 40.26^{\text {ghi }}(3.5 \%)$ \\
\hline B-2-8 & $16,272.83 \pm 1808.31^{e f}$ & $15,757.86 \pm 1808.31^{\text {ef }}(96.84 \%)$ & $514.97 \pm 66.57^{f}(3.16 \%)$ \\
\hline Z1 & $4965.79 \pm 548.09^{\mathrm{ijk}}$ & $4526.59 \pm 548.09^{\mathrm{ijk}}(91.16 \%)$ & $439.19 \pm 56.41 \mathrm{fg}(8.84 \%)$ \\
\hline $\mathrm{Z2}$ & $5984.99 \pm 571.56 \mathrm{~h}^{\mathrm{ijk}}$ & $5110.54 \pm 571.56^{\mathrm{ijk}}(85.39 \%)$ & $874.44 \pm 95.62^{b}(14.61 \%)$ \\
\hline Z4 & $7498.51 \pm 682.07^{h i j}$ & $6746.59 \pm 682.07^{\mathrm{jk}}(89.97 \%)$ & $751.92 \pm 87.75^{c d}(10.03 \%)$ \\
\hline CGS & $51,811.86 \pm 5233.05^{\mathrm{a}}$ & $51,279.3 \pm 5233.05^{\mathrm{a}}(98.97 \%)$ & $532.56 \pm 46.46^{\mathrm{ef}}(1.03 \%)$ \\
\hline T6 & $13,490.12 \pm 1792.09^{\mathrm{fg}}$ & $12,954.33 \pm 1792.09^{\mathrm{fg}}(96.03 \%)$ & $535.78 \pm 65.37^{\mathrm{ef}}(3.97 \%)$ \\
\hline $\mathrm{T7}$ & $8068.84 \pm 973.34^{\mathrm{hi}}$ & $7828.8 \pm 973.34^{h i}(97.03 \%)$ & $240.04 \pm 27.12^{\mathrm{ij}}(2.97 \%)$ \\
\hline BR60 & $4545.99 \pm 456.22^{\mathrm{ijk}}$ & $4300.87 \pm 456.22^{\mathrm{ijk}}(94.61 \%)$ & $245.12 \pm 27.41^{\mathrm{ij}}(5.39 \%)$ \\
\hline S54 & $4000 \pm 397.67^{\mathrm{jk}}$ & $3693.5 \pm 397.67^{\mathrm{jk}}(92.34 \%)$ & $306.5 \pm 34.73^{\text {hij }}(7.66 \%)$ \\
\hline QM & $16,748.36 \pm 2401.89^{\mathrm{ef}}$ & $16,240.99 \pm 2401.89^{e f}(96.97 \%)$ & $507.38 \pm 53.43^{f}(3.03 \%)$ \\
\hline$J 4-1$ & $18,463.88 \pm 2285.15^{e}$ & $17,712.43 \pm 2285.15^{\mathrm{e}}(95.93 \%)$ & $751.45 \pm 80.13^{c d}(4.07 \%)$ \\
\hline$J 5$ & $7082.78 \pm 636.06^{\text {hij }}$ & $6796.07 \pm 636.06^{\mathrm{ijk}}(95.95 \%)$ & $286.71 \pm 27.65^{\text {hij }}(4.05 \%)$ \\
\hline Y2 & $23,833.07 \pm 2884.06^{d}$ & $23,127.05 \pm 2884.06^{d}(97.04 \%)$ & $706.03 \pm 74.29^{d}(2.96 \%)$ \\
\hline YXM2 & $8235.79 \pm 611.32^{\text {hi }}$ & $7849.57 \pm 611.32^{h i}(95.31 \%)$ & $386.21 \pm 36.6^{g h}(4.69 \%)$ \\
\hline YD & $25,720.37 \pm 3059.38^{\mathrm{cd}}$ & $25,347.54 \pm 3059.38^{c d}(98.55 \%)$ & $372.83 \pm 33.87^{g h}(1.45 \%)$ \\
\hline Y1 & $39,120.86 \pm 3514.82^{b}$ & $38,478.25 \pm 3514.82^{b}(98.36 \%)$ & $642.61 \pm 60.36^{\text {de }}(1.64 \%)$ \\
\hline
\end{tabular}

Different letters indicate significant differences in total, free, and bound phenolic contents in 23 mulberry leaf samples $(P<0.05)$ Values with no letters in common in each column are significantly different $(P<0.05), n=3$

Values in parentheses indicate the percentage contributions of the free and bound fractions to the total phenolic content for each sample

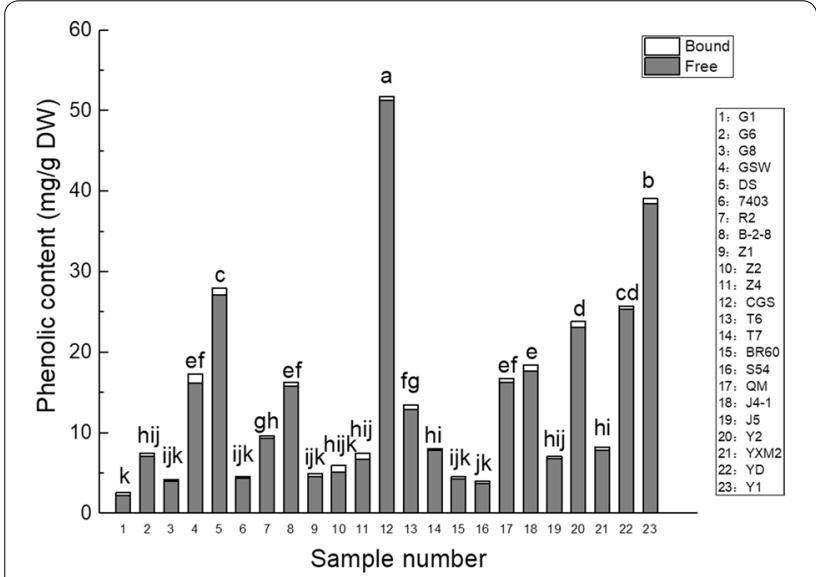

Fig. 1 Free and bound phenolic contents of the 23 mulberry leaf samples

mulberry leaf cultivars from the same geographical area varied considerably; for instance, GSW, DS, Z4, QM, J4-1, Y2, and Y1 displayed the highest free phenolic contents of the specimens from North China, South China,
Southwest China, Thailand, Japan, India, and Vietnam, respectively.

\section{Free and bound phenolic profiles}

Chromatograms of phenolic compounds of the leaves of the mulberry varieties from Z2 are shown in Figs. 2 and 3 . Identify the main phenolic compounds by comparing the retention time and other data of the standards. In addition, phenolic compounds are quantified by using a corresponding standard curve with a higher correlation value. Tables 6 and 7 summarize the contents of each phenolic substance in the mulberry leaf samples in the free and bound states, respectively. As shown in Table 6, HPLC analysis revealed the presence of 11 phenolic compounds in the free state, of which ChA, Epi, CaA, Rut, Iso, and Ast together accounted for over $50 \%$ of the free phenolic content. This result is consistent with previous reports by Zou et al. [40] and Onogi et al. [25]. The values of ChA ranged from 1.396 to $44.627 \mathrm{mg} / \mathrm{g}$ DW and essentially determined the free phenolic content of the mulberry leaves. The leaves of the mulberry varieties from Vietnam (YD and Y1) and Taiwan (CGS) were found 


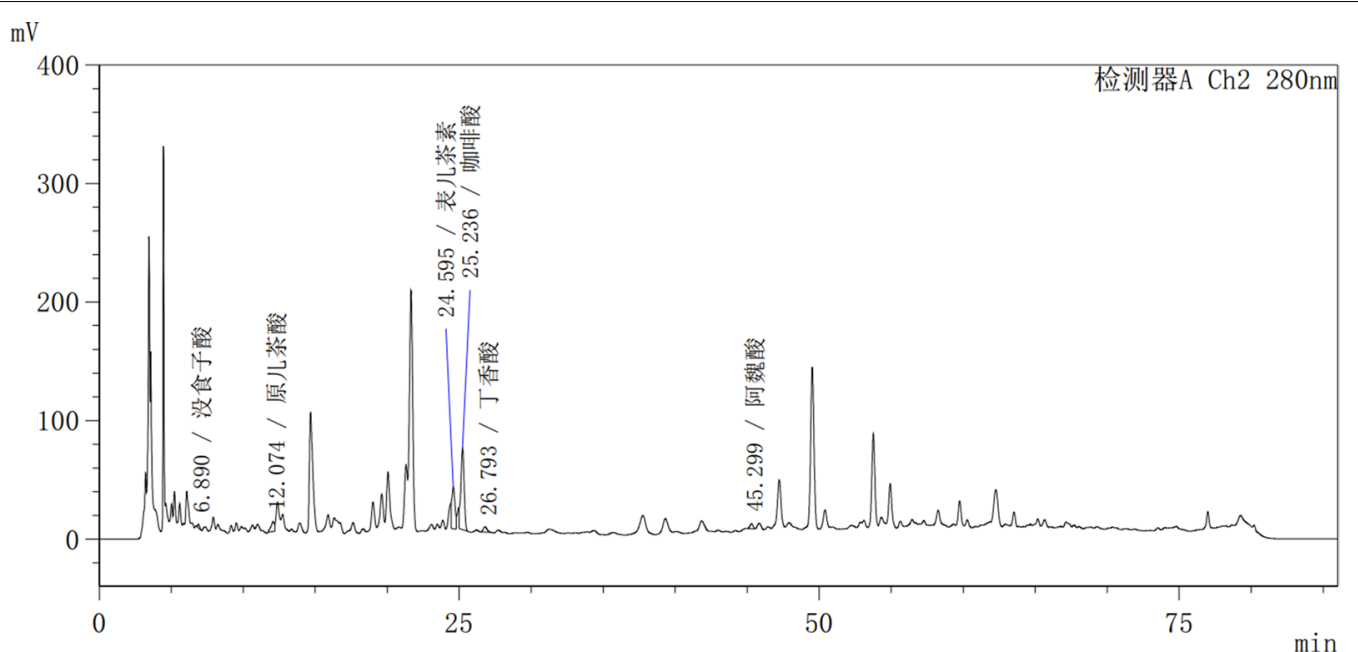

Fig. 2 HPLC Chromatograms at $280 \mathrm{~nm}$ of the leaves of the mulberry varieties from Z2

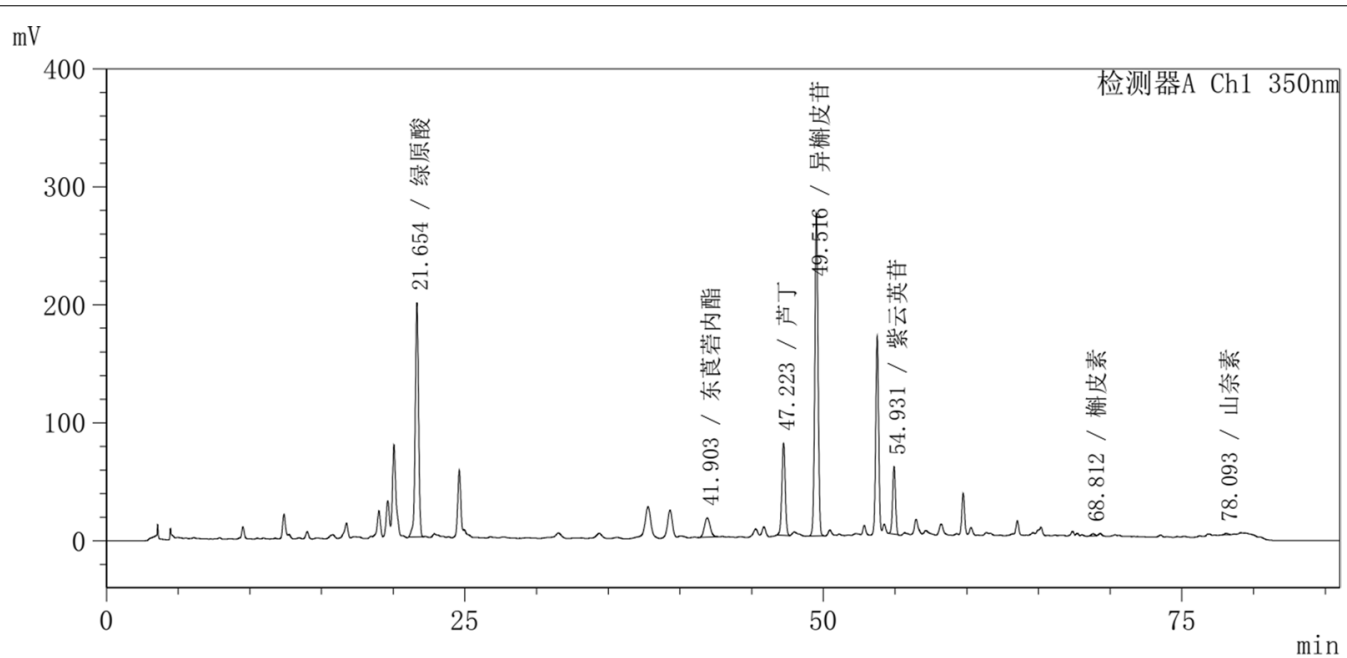

Fig. 3 HPLC Chromatograms at $350 \mathrm{~nm}$ of the leaves of the mulberry varieties from Z2

to be especially rich in ChA. As mentioned in previous reports $[17,28]$, ChA can serve as an antioxidant in vitro and may hinder the formation of mutagenic and carcinogenic $N$-nitroso compounds by inhibiting $N$-nitrosation reactions. Furthermore, ChA was reported to inhibit the oxidation of low-density lipoprotein in vitro and could protect against cardiovascular disease [19]. Hence, ChA could potentially be extracted from mulberry leaves and refined for use as a medicine to treat human diseases.

As shown in Table 6, the leaves of the various mulberry cultivars contained different amounts of individual phenolic compounds. However, not all of the 11 phenolic compounds were detected in all samples; for example, BeA was only observed in G6 and G8, while Sco was only found in G1, R2, Z2, QM, BR60, J4-1, J5, Y1. Although none of the 23 cultivars contained all 11 components, J4-1,R2, Z2 and J5 were the richest in free phenolic compounds among the samples tested, with ten components detected. In contrast, YD contained the smallest variety of phenolic compounds, with only six of the components detected.

As shown in Table 7, CaA, Iso, Ast, PrA, FeA, and SyA accounted for the majority of the bound phenolic content for most of the samples, although Iso and PrA were not detected in G8 and SyA was not detected in Z4. Among these six main bound phenolic compounds, $\mathrm{CaA}$ was the major component. Previous studies have indicated that $\mathrm{CaA}$, as an $\alpha$-tocopherol protectant in low-density lipoprotein, is a superior antioxidant compared with FeA, which can also serve as a potent antioxidant to eliminate 
Table 6 Free phenolic compounds detected in the 23 mulberry leaf samples by HPLC

\begin{tabular}{|c|c|c|c|c|c|c|}
\hline $\begin{array}{l}\text { Compound } \\
\text { (mg/g DW) }\end{array}$ & ChA & Epi & $\mathrm{CaA}$ & Rut & Iso & Ast \\
\hline G1 & $1.396 \pm 0.128^{j}$ & $0.3 \pm 0.039^{g h}$ & $0.126 \pm 0.016^{c d}$ & $0.073 \pm 0.01^{k}$ & $0.178 \pm 0.017^{k}$ & $0.123 \pm 0.008^{\mathrm{Im}}$ \\
\hline G6 & $4.268 \pm 0.65^{\text {ghij }}$ & $0.73 \pm 0.096^{b c}$ & $0.124 \pm 0.016^{c d}$ & $0.309 \pm 0.043^{\mathrm{ijk}}$ & $0.854 \pm 0.089^{f}$ & $0.756 \pm 0.071^{\mathrm{ef}}$ \\
\hline G8 & $2.402 \pm 0.242^{i j}$ & $0.388 \pm 0.052^{\text {efgh }}$ & $0.145 \pm 0.03^{c}$ & $0.285 \pm 0.055^{\mathrm{ijk}}$ & $0.513 \pm 0.063^{\text {fghijk }}$ & $0.183 \pm 0.042^{\mathrm{ijk} k \mathrm{~m}}$ \\
\hline GSW & $12.603 \pm 1.26^{d}$ & $0.467 \pm 0.061^{e}$ & $0.047 \pm 0.006^{\mathrm{fgh}}$ & $1.068 \pm 0.085^{\mathrm{de}}$ & $1.494 \pm 0.194^{\mathrm{de}}$ & $0.472 \pm 0.058^{g}$ \\
\hline R2 & $21.127 \pm 1.93^{c}$ & $0.81 \pm 0.088^{a b}$ & $0.235 \pm 0.049^{a b}$ & $1.136 \pm 0.179^{d}$ & $2.093 \pm 0.216^{b}$ & $1.553 \pm 0.228^{\mathrm{a}}$ \\
\hline 7403 & $3.122 \pm 0.301^{h i j}$ & $0.3 \pm 0.025^{g h}$ & $0.037 \pm 0.003^{g h}$ & $0.181 \pm 0.019^{\mathrm{ijk}}$ & $0.29 \pm 0.028^{i j k}$ & $0.274 \pm 0.022^{h i j k l}$ \\
\hline DS & $7.494 \pm 0.614^{e}$ & $0.338 \pm 0.036^{\mathrm{fgh}}$ & $0.223 \pm 0.031^{b}$ & $0.409 \pm 0.033^{h i j k}$ & $0.447 \pm 0.041^{g h i j k}$ & $0.279 \pm 0.052^{\mathrm{hijkl}}$ \\
\hline B-2-8 & $13.766 \pm 1.593^{d}$ & $0.352 \pm 0.043^{\text {efgh }}$ & $0.045 \pm 0.006^{g h}$ & $0.252 \pm 0.046^{\mathrm{ijk}}$ & $0.733 \pm 0.061^{\mathrm{fg}}$ & $0.46 \pm 0.039^{9}$ \\
\hline $\mathrm{Z1}$ & $3.49 \pm 0.416^{\text {ghij }}$ & $0.341 \pm 0.035^{\mathrm{fgh}}$ & $0.071 \pm 0.009^{\mathrm{efg}}$ & $0.134 \pm 0.025^{\mathrm{jk}}$ & $0.341 \pm 0.045^{h i j k}$ & $0.067 \pm 0.009^{m}$ \\
\hline $\mathrm{Z} 2$ & $3.42 \pm 0.333^{\text {ghij }}$ & $0.376 \pm 0.071^{\mathrm{efgh}}$ & $0.118 \pm 0.013^{c d}$ & $0.289 \pm 0.044^{\mathrm{ijk}}$ & $0.681 \pm 0.071^{\mathrm{fgh}}$ & $0.14 \pm 0.026^{\mathrm{klm}}$ \\
\hline Z4 & $4.9 \pm 0.433^{\text {fghi }}$ & $0.395 \pm 0.052^{\text {efg }}$ & $0.277 \pm 0.053^{\mathrm{a}}$ & $0.305 \pm 0.043^{\mathrm{ijk}}$ & $0.631 \pm 0.056^{\mathrm{fghi}}$ & $0.16 \pm 0.032^{\mathrm{jklm}}$ \\
\hline CGS & $44.627 \pm 4.149^{a}$ & $0.295 \pm 0.056^{g h}$ & $0.042 \pm 0.005^{g h}$ & $2.248 \pm 0.417^{c}$ & $3.187 \pm 0.476^{\mathrm{a}}$ & $0.754 \pm 0.1^{\mathrm{ef}}$ \\
\hline T6 & $8.47 \pm 1.062^{e}$ & $0.432 \pm 0.073^{e f}$ & $0.091 \pm 0.011^{\text {def }}$ & $1.263 \pm 0.194^{d}$ & $1.881 \pm 0.35^{b c}$ & $0.672 \pm 0.073^{f}$ \\
\hline $\mathrm{T7}$ & $5.627 \pm 0.737^{\text {efgh }}$ & $0.756 \pm 0.07^{b c}$ & $0.032 \pm 0.004^{g h}$ & $0.411 \pm 0.045^{h i j k}$ & $0.582 \pm 0.049^{\text {fghij }}$ & $0.354 \pm 0.056^{g h i}$ \\
\hline QM & $2.695 \pm 0.326^{h i j}$ & $0.313 \pm 0.029^{g h}$ & $0.041 \pm 0.003^{g h}$ & $0.416 \pm 0.032^{h i j}$ & $0.412 \pm 0.021^{\text {ghijk }}$ & $0.315 \pm 0.033^{g h i j k}$ \\
\hline $\mathrm{BR} 60$ & $2.217 \pm 0.242^{i j}$ & $0.302 \pm 0.032^{g h}$ & $0.059 \pm 0.005^{\mathrm{fgh}}$ & $0.378 \pm 0.042^{h i j k}$ & $0.382 \pm 0.038^{g h i j k}$ & $0.257 \pm 0.025^{\text {hijkl }}$ \\
\hline S54 & $12.413 \pm 1.943^{d}$ & $0.601 \pm 0.065^{d}$ & $0.09 \pm 0.009^{\mathrm{def}}$ & $0.931 \pm 0.09^{\text {def }}$ & $1.231 \pm 0.159^{e}$ & $0.861 \pm 0.114^{\mathrm{de}}$ \\
\hline$J 4-1$ & $12.969 \pm 1.612^{d}$ & $0.923 \pm 0.098^{a}$ & $0.25 \pm 0.044^{\mathrm{ab}}$ & $0.771 \pm 0.074^{\mathrm{efg}}$ & $1.555 \pm 0.279^{\text {cde }}$ & $1.044 \pm 0.143^{b c}$ \\
\hline $\mathrm{J} 5$ & $4.577 \pm 0.509^{f g h i}$ & $0.276 \pm 0.041^{h}$ & $0.053 \pm 0.009^{f g h}$ & $0.666 \pm 0.097^{f g h}$ & $0.619 \pm 0.084^{\mathrm{fghi}}$ & $0.367 \pm 0.056^{g h}$ \\
\hline $\mathrm{Y} 2$ & $18.341 \pm 2.335^{c}$ & $0.666 \pm 0.092^{c d}$ & $0.109 \pm 0.014^{\text {cde }}$ & $1.165 \pm 0.133^{d}$ & $1.739 \pm 0.165^{\mathrm{bcd}}$ & $0.934 \pm 0.121^{c d}$ \\
\hline YXM2 & $6.429 \pm 0.437^{\mathrm{efg}}$ & $0.282 \pm 0.033^{g h}$ & $0.133 \pm 0.024^{c d}$ & $0.507 \pm 0.047^{g h i}$ & $0.237 \pm 0.029^{k}$ & $0.136 \pm 0.022^{\mathrm{Im}}$ \\
\hline YD & $19.797 \pm 2.348^{c}$ & $0.153 \pm 0.026^{i}$ & $0.017 \pm 0.002^{h}$ & $3.57 \pm 0.468^{b}$ & $1.332 \pm 0.135^{e}$ & $0.336 \pm 0.062^{g h i j}$ \\
\hline $\mathrm{Y} 1$ & $29.099 \pm 2.512^{b}$ & $0.367 \pm 0.037^{\text {efgh }}$ & $0.035 \pm 0.005^{g h}$ & $4.397 \pm 0.352^{\mathrm{a}}$ & $3.077 \pm 0.363^{\mathrm{a}}$ & $1.128 \pm 0.184^{b}$ \\
\hline $\begin{array}{l}\text { Compound } \\
\text { (mg/g DW) }\end{array}$ & PrA & Que & & $\mathrm{GaA}$ & Sco & $\mathrm{BeA}$ \\
\hline G1 & $0.029 \pm 0.005^{g h}$ & ND & & $0.018 \pm 0.002^{c}$ & $0.002 \pm 0^{c}$ & ND \\
\hline G6 & ND & ND & & $0.024 \pm 0.004^{b}$ & $N D$ & $0.03 \pm 0.004^{\mathrm{a}}$ \\
\hline G8 & $0.032 \pm 0.005^{\text {defgh }}$ & ND & & $0.017 \pm 0.002^{c d}$ & $N D$ & $0.021 \pm 0.004^{a}$ \\
\hline GSW & ND & 0.018 & $002^{\mathrm{a}}$ & $0.007 \pm 0.001^{g h i}$ & ND & ND \\
\hline $\mathrm{R} 2$ & $0.033 \pm 0.003^{\text {defg }}$ & 0.016 & $002^{a b c}$ & $0.002 \pm 0^{k l}$ & $0.004 \pm 0^{c}$ & ND \\
\hline 7403 & $0.036 \pm 0.003^{\text {bcdefg }}$ & 0.015 & $002^{\mathrm{abc}}$ & $0.037 \pm 0.004^{\mathrm{a}}$ & ND & ND \\
\hline DS & $0.034 \pm 0.004^{\text {cdefg }}$ & 0.013 & $003^{b c}$ & $0.011 \pm 0.002^{e f}$ & ND & ND \\
\hline B-2-8 & $0.03 \pm 0.004^{g h}$ & 0.014 & $003^{b c}$ & $0.004 \pm 0.001^{h i j k l}$ & ND & ND \\
\hline $\mathrm{Z1}$ & $0.032 \pm 0.005^{\text {defgh }}$ & 0.017 & $002^{a b}$ & $0.018 \pm 0.002^{c d}$ & ND & ND \\
\hline $\mathrm{Z2}$ & $0.044 \pm 0.007^{b c d}$ & 0.015 & $002^{a b c}$ & $0.005 \pm 0.001^{h i j k}$ & $0.006 \pm 0.001^{c}$ & ND \\
\hline Z4 & $0.048 \pm 0.009^{\mathrm{ab}}$ & 0.013 & $002^{b c}$ & $0.01 \pm 0.001^{\mathrm{fg}}$ & ND & ND \\
\hline CGS & ND & 0.013 & $003^{b c}$ & ND & ND & ND \\
\hline T6 & $0.03 \pm 0.007^{f g h}$ & 0.013 & $003^{b c}$ & $0.003 \pm 0.001^{\mathrm{jkl}}$ & ND & ND \\
\hline $\mathrm{T} 7$ & $0.031 \pm 0.007^{\text {efgh }}$ & ND & & $0.007 \pm 0.001^{g h}$ & ND & ND \\
\hline $\mathrm{QM}$ & $0.042 \pm 0.004^{\text {bcdef }}$ & 0.012 & $001^{c}$ & $0.005 \pm 0.001^{h i j}$ & $0.014 \pm 0.002^{c}$ & ND \\
\hline $\mathrm{BR60}$ & $0.056 \pm 0.007^{a}$ & ND & & $0.003 \pm 0^{\mathrm{ijkl}}$ & $0.015 \pm 0.002^{c}$ & ND \\
\hline S54 & $0.043 \pm 0.009^{b c d e}$ & ND & & $0.005 \pm 0.001^{h i j k}$ & ND & ND \\
\hline$J 4-1$ & $0.025 \pm 0.006^{g h}$ & 0.016 & $002^{a b c}$ & $0.005 \pm 0.001^{h i j k}$ & $0.005 \pm 0.001^{c}$ & ND \\
\hline $\mathrm{J} 5$ & $0.045 \pm 0.005^{\mathrm{abc}}$ & 0.012 & $002^{c}$ & $0.006 \pm 0.001^{h i j}$ & $0.07 \pm 0.008^{b}$ & ND \\
\hline$Y 2$ & $0.02 \pm 0.005^{h}$ & 0.015 & $002^{a b c}$ & $0.001 \pm 0^{1}$ & ND & ND \\
\hline YXM2 & $0.029 \pm 0.006^{g h}$ & ND & & $0.014 \pm 0.002^{\text {de }}$ & ND & ND \\
\hline YD & ND & ND & & ND & ND & ND \\
\hline $\mathrm{Y} 1$ & ND & 0.014 & $003^{a b c}$ & ND & $0.13 \pm 0.023^{a}$ & ND \\
\hline
\end{tabular}

\section{$N D$ not detected}

Different letters indicate significant differences in free phenolic compounds detected in the 23 mulberry leaf samples by HPLC $(P<0.05)$

Values with no letters in common in each column are significantly different $(P<0.05), n=3$ 
Table 7 Bound phenolic compounds detected in the 23 mulberry leaf samples by HPLC

\begin{tabular}{|c|c|c|c|c|c|}
\hline $\begin{array}{l}\text { Compound } \\
\text { (mg/g DW) }\end{array}$ & $\mathrm{CaA}$ & Iso & Ast & PrA & $\mathrm{FeA}$ \\
\hline G1 & $0.125 \pm 0.021^{j}$ & $0.086 \pm 0.008^{\mathrm{fgh}}$ & $0.049 \pm 0.006^{e f}$ & $0.02 \pm 0.003^{e f}$ & $0.013 \pm 0.003^{\mathrm{abc}}$ \\
\hline G6 & $0.133 \pm 0.022^{j}$ & $0.08 \pm 0.008^{\mathrm{fghi}}$ & $0.068 \pm 0.008^{d}$ & $0.016 \pm 0.002^{\text {efgh }}$ & $0.005 \pm 0.00 \mathrm{j}^{\mathrm{jkm}}$ \\
\hline G8 & $0.141 \pm 0.024^{j}$ & ND & $0.027 \pm 0.003^{g h i j}$ & ND & $0.011 \pm 0.002^{\text {cdef }}$ \\
\hline GSW & $0.531 \pm 0.04^{\mathrm{a}}$ & $0.412 \pm 0.04^{\mathrm{a}}$ & $0.059 \pm 0.008^{\mathrm{de}}$ & $0.046 \pm 0.007^{\mathrm{a}}$ & $0.012 \pm 0.003^{\mathrm{abcd}}$ \\
\hline R2 & $0.317 \pm 0.024^{\text {def }}$ & $0.25 \pm 0.022^{c}$ & $0.185 \pm 0.023^{\mathrm{a}}$ & $0.016 \pm 0.003^{\text {efgh }}$ & $0.011 \pm 0.002^{\text {bcde }}$ \\
\hline 7403 & $0.123 \pm 0.018^{j}$ & $0.047 \pm 0.005^{i j}$ & $0.04 \pm 0.006^{\mathrm{fg}}$ & $0.018 \pm 0.003^{\text {defg }}$ & $0.014 \pm 0.003^{\mathrm{ab}}$ \\
\hline DS & $0.201 \pm 0.021^{\mathrm{hj}}$ & $0.044 \pm 0.006^{i j}$ & $0.017 \pm 0.003^{i j}$ & $0.013 \pm 0.002^{g h}$ & $0.013 \pm 0.002^{\mathrm{abc}}$ \\
\hline B-2-8 & $0.263 \pm 0.031^{\mathrm{fg}}$ & $0.127 \pm 0.02^{\mathrm{e}}$ & $0.072 \pm 0.007^{d}$ & $0.003 \pm 0^{j}$ & $0.004 \pm 0^{\mathrm{klm}}$ \\
\hline $\mathrm{Z1}$ & $0.284 \pm 0.035^{\mathrm{fg}}$ & $0.081 \pm 0.011^{f g h i}$ & $0.017 \pm 0.003^{i j}$ & $0.023 \pm 0.003^{c d}$ & $0.007 \pm 0.001^{\text {hijkl }}$ \\
\hline $\mathrm{Z2}$ & $0.365 \pm 0.039^{c d}$ & $0.357 \pm 0.035^{b}$ & $0.032 \pm 0.005^{g h i}$ & $0.032 \pm 0.004^{b}$ & $0.009 \pm 0.001^{e^{\text {fghi }}}$ \\
\hline Z4 & $0.359 \pm 0.038^{\text {cde }}$ & $0.255 \pm 0.034^{c}$ & $0.036 \pm 0.004^{\mathrm{fgh}}$ & $0.028 \pm 0.003^{b c}$ & $0.01 \pm 0.001^{\text {defg }}$ \\
\hline CGS & $0.383 \pm 0.034^{c}$ & $0.075 \pm 0.006^{g h i}$ & $0.022 \pm 0.002^{\text {hij }}$ & $0.008 \pm 0^{\mathrm{ij}}$ & $0.007 \pm 0.001^{g h i j k}$ \\
\hline T6 & $0.198 \pm 0.024^{\mathrm{hi}}$ & $0.198 \pm 0.028^{d}$ & $0.063 \pm 0.005^{\text {de }}$ & $0.012 \pm 0.002^{\mathrm{hi}}$ & $0.009 \pm 0.001^{\text {defghi }}$ \\
\hline $\mathrm{T7}$ & $0.094 \pm 0.01^{j}$ & $0.057 \pm 0.007^{g^{h i j}}$ & $0.033 \pm 0.003^{g h i}$ & $0.014 \pm 0.002^{g h}$ & $0.014 \pm 0.002^{\mathrm{abc}}$ \\
\hline $\mathrm{QM}$ & $0.108 \pm 0.012^{j}$ & $0.046 \pm 0.005^{i j}$ & $0.018 \pm 0.002^{i j}$ & $0.016 \pm 0.001^{\mathrm{efgh}}$ & $0.007 \pm 0^{\mathrm{jjk} k m}$ \\
\hline BR60 & $0.147 \pm 0.017^{i j}$ & $0.062 \pm 0.007^{\text {ghij }^{h}}$ & $0.022 \pm 0.003^{\mathrm{hij}}$ & $0.018 \pm 0.002^{\text {defg }}$ & $0.004 \pm 0^{m}$ \\
\hline S54 & $0.307 \pm 0.03^{e f}$ & $0.116 \pm 0.013^{e f}$ & $0.028 \pm 0.004^{\text {ghij }}$ & $0.016 \pm 0.002^{\mathrm{fgh}}$ & $0.008 \pm 0^{\text {fghi }}$ \\
\hline$J 4-1$ & $0.314 \pm 0.026^{\text {def }}$ & $0.209 \pm 0.025^{d}$ & $0.135 \pm 0.019^{b}$ & $0.022 \pm 0.003^{d}$ & $0.015 \pm 0.002^{\mathrm{a}}$ \\
\hline 15 & $0.138 \pm 0.01^{j}$ & $0.051 \pm 0.007^{\mathrm{hij}}$ & $0.02 \pm 0.001^{\mathrm{ij}}$ & $0.012 \pm 0.002^{\mathrm{hi}}$ & $0.007 \pm 0.001^{g^{\text {hij }}}$ \\
\hline$Y_{2}$ & $0.307 \pm 0.031^{\mathrm{ef}}$ & $0.22 \pm 0.024^{c d}$ & $0.099 \pm 0.011^{c}$ & $0.021 \pm 0.002^{\mathrm{de}}$ & $0.009 \pm 0.001^{\text {efghi }}$ \\
\hline YXM2 & $0.273 \pm 0.022^{\mathrm{fg}}$ & $0.032 \pm 0.004^{j}$ & $0.014 \pm 0.002^{j}$ & $0.011 \pm 0.002^{h i}$ & $0.01 \pm 0.001^{\text {defgh }}$ \\
\hline YD & $0.23 \pm 0.02^{g h}$ & $0.06 \pm 0.006^{\text {ghij }}$ & $0.016 \pm 0.002^{j}$ & $0.003 \pm 0^{j}$ & $0.008 \pm 0.001^{\text {ghij }}$ \\
\hline$Y_{1}$ & $0.468 \pm 0.045^{b}$ & $0.09 \pm 0.006^{\mathrm{efg}}$ & ND & $0.006 \pm 0.001^{j}$ & $0.004 \pm 0^{\mathrm{lm}}$ \\
\hline $\begin{array}{l}\text { Compound } \\
\text { (mg/g DW) }\end{array}$ & SyA & Quer & Rut & $\mathrm{GaA}$ & BeA \\
\hline G1 & $0.004 \pm 0.001^{\prime}$ & ND & ND & ND & $0.002 \pm 0^{\mathrm{a}}$ \\
\hline G6 & $0.006 \pm 0.001^{\mathrm{jkl}}$ & ND & $0.01 \pm 0.001^{g}$ & ND & $0.001 \pm 0^{b}$ \\
\hline G8 & $0.005 \pm 0.001^{\mathrm{jkl}}$ & ND & ND & $0.001 \pm 0^{e}$ & $0.001 \pm 0^{b}$ \\
\hline GSW & $0.01 \pm 0.002^{g h i}$ & $0.008 \pm 0.001^{\mathrm{a}}$ & $0.032 \pm 0.004^{\mathrm{a}}$ & $0.001 \pm 0^{c d}$ & ND \\
\hline R2 & $0.021 \pm 0.003^{c}$ & $0.007 \pm 0.001^{\mathrm{ab}}$ & ND & ND & ND \\
\hline 7403 & $0.003 \pm 0^{\prime}$ & $0.007 \pm 0.001^{\mathrm{ab}}$ & $0.01 \pm 0.002^{g}$ & $0.001 \pm 0^{e}$ & ND \\
\hline DS & $0.009 \pm 0.001^{\mathrm{hij}}$ & $0.007 \pm 0.001^{\mathrm{ab}}$ & $0.012 \pm 0.002^{\mathrm{efg}}$ & $0.001 \pm 0^{e}$ & ND \\
\hline B-2-8 & $0.014 \pm 0.002^{\mathrm{ef}}$ & $0.006 \pm 0.001^{b}$ & ND & ND & ND \\
\hline $\mathrm{Z1}$ & $0.007 \pm 0.001^{\mathrm{jkl}}$ & $0.007 \pm 0.001^{\mathrm{ab}}$ & $0.011 \pm 0.002^{\mathrm{fg}}$ & $0.003 \pm 0^{\mathrm{a}}$ & ND \\
\hline $\mathrm{Z2}$ & $0.008 \pm 0.001^{\mathrm{ijk}}$ & $0.007 \pm 0.001^{\mathrm{ab}}$ & $0.02 \pm 0.002^{b}$ & $0.001 \pm 0 c$ & ND \\
\hline Z4 & ND & $0.007 \pm 0.001^{\mathrm{ab}}$ & $0.017 \pm 0.002^{\mathrm{bcd}}$ & $0.001 \pm 0^{b}$ & ND \\
\hline CGS & $0.019 \pm 0.002^{\mathrm{cd}}$ & ND & $0.017 \pm 0.002^{\mathrm{bcd}}$ & $0.001 \pm 0^{e}$ & ND \\
\hline T6 & $0.014 \pm 0.002^{\mathrm{ef}}$ & $0.007 \pm 0^{\mathrm{ab}}$ & $0.034 \pm 0.004^{\mathrm{a}}$ & $0.001 \pm 0^{\text {de }}$ & ND \\
\hline $\mathrm{T} 7$ & $0.004 \pm 0.001^{1}$ & $0.006 \pm 0.001^{b}$ & ND & $0.001 \pm 0^{\text {de }}$ & ND \\
\hline $\mathrm{QM}$ & $0.005 \pm 0^{\mathrm{kl}}$ & $0.007 \pm 0.001^{\mathrm{ab}}$ & $0.013 \pm 0.002^{\text {defg }}$ & $0.001 \pm 0^{\text {cde }}$ & ND \\
\hline BR60 & $0.007 \pm 0.001^{\mathrm{ijk}}$ & ND & $0.016 \pm 0.002^{\text {bcde }}$ & $0.001 \pm 0^{\mathrm{e}}$ & ND \\
\hline S54 & $0.013 \pm 0.002^{\mathrm{fg}}$ & ND & ND & $0.001 \pm 0^{e}$ & ND \\
\hline$J 4-1$ & $0.017 \pm 0.001^{\text {de }}$ & $0.007 \pm 0.001^{\mathrm{ab}}$ & $0.018 \pm 0.002^{b c}$ & $0.001 \pm 0^{e}$ & ND \\
\hline$J 5$ & $0.008 \pm 0.001^{\mathrm{ij}}$ & $0.007 \pm 0.001^{\mathrm{ab}}$ & $0.015 \pm 0.001^{\text {cdef }}$ & ND & ND \\
\hline$Y_{2}$ & $0.027 \pm 0.002^{b}$ & ND & ND & $0.001 \pm 0^{\text {cde }}$ & ND \\
\hline YXM2 & $0.012 \pm 0.001^{\mathrm{fgh}}$ & ND & $0.016 \pm 0.002^{b c d e}$ & $0.001 \pm 0^{\text {cde }}$ & ND \\
\hline YD & $0.021 \pm 0.002^{c}$ & ND & $0.031 \pm 0.002^{\mathrm{a}}$ & ND & ND \\
\hline $\mathrm{Y}_{1}$ & $0.035 \pm 0.004^{\mathrm{a}}$ & $0.007 \pm 0.001^{\mathrm{ab}}$ & $0.033 \pm 0.004^{\mathrm{a}}$ & ND & ND \\
\hline
\end{tabular}


Table 7 (continued)

\section{ND not detected}

Different letters indicate significant differences in bound phenolic compounds detected in the 23 mulberry leaf samples by HPLC $(P<0.05)$

Values with no letters in common in each column are significantly different $(P<0.05), n=3$

Table 8 Antioxidant activities of the free phenolic fractions of the 23 mulberry leaf samples

\begin{tabular}{|c|c|c|c|}
\hline Cultivar & $\begin{array}{l}\text { FRAP } \\
\left(\mu \mathrm{mol} \mathrm{Fe} e^{2+} / g \text { DW }\right)\end{array}$ & $\begin{array}{l}\text { ABTS } \\
(\mu \mathrm{mol} \text { TEAC/g DW) }\end{array}$ & $\begin{array}{l}\text { DPPH } \\
(\mu \mathrm{mol} \text { AEAC/g DW })\end{array}$ \\
\hline G1 & $35.13 \pm 2.47^{h}$ & $23.53 \pm 1.66^{g h}$ & $23.11 \pm 1.91^{i}$ \\
\hline G6 & $70.21 \pm 5.63^{\mathrm{ef}}$ & $32.98 \pm 2.64^{9}$ & $55.21 \pm 4.43^{\mathrm{efg}}$ \\
\hline G8 & $47.33 \pm 4.95^{\mathrm{fgh}}$ & $24.97 \pm 2.57^{g h}$ & $33.87 \pm 3.54^{g h_{i}}$ \\
\hline GSW & $108.14 \pm 11.13^{d}$ & $45.52 \pm 4.68^{f}$ & $102.77 \pm 10.57^{d}$ \\
\hline R2 & $66.68 \pm 5.95^{\mathrm{ef}}$ & $30.04 \pm 2.68^{g h}$ & $40.81 \pm 3.64^{\mathrm{fghi}}$ \\
\hline 7403 & $41 \pm 3.46^{g h}$ & $19.81 \pm 1.67^{h}$ & $26.37 \pm 2.23^{c}$ \\
\hline DS & $166.13 \pm 16.59^{c}$ & $81.23 \pm 8.11^{c}$ & $158.15 \pm 15.79^{i}$ \\
\hline B-2-8 & $79.97 \pm 9.18^{\mathrm{ef}}$ & $35.74 \pm 4.1^{\mathrm{fg}}$ & $41.23 \pm 4.73^{\mathrm{fghi}}$ \\
\hline Z1 & $40.72 \pm 4.93^{g h}$ & $25.08 \pm 3.04^{g h}$ & $30.04 \pm 3.64^{\mathrm{hi}}$ \\
\hline Z2 & $53.17 \pm 5.95^{\mathrm{fgh}}$ & $28.66 \pm 3.21^{g h}$ & $42.01 \pm 4.7^{f g h i}$ \\
\hline Z4 & $55.91 \pm 5.65^{\mathrm{efgh}}$ & $32.27 \pm 3.26^{g h}$ & $44 \pm 4.45^{f_{g h i}}$ \\
\hline CGS & $227.8 \pm 23.25^{\mathrm{a}}$ & $96.22 \pm 9.82^{b}$ & $256.63 \pm 26.19^{a}$ \\
\hline T6 & $129.14 \pm 17.87^{d}$ & $63.25 \pm 8.75^{d}$ & $100.27 \pm 13.87^{d}$ \\
\hline $\mathrm{T} 7$ & $63.16 \pm 7.85^{\mathrm{efg}}$ & $28.73 \pm 3.57^{g h}$ & $43.08 \pm 5.36^{\mathrm{fghi}}$ \\
\hline QM & $41.26 \pm 4.44^{g h}$ & $25.09 \pm 2.7^{g h}$ & $37.15 \pm 4^{g h i}$ \\
\hline BR60 & $105.83 \pm 15.65^{d}$ & $48.07 \pm 7.11^{\mathrm{ef}}$ & $97.37 \pm 14.4^{d}$ \\
\hline S54 & $45.76 \pm 4.85^{\mathrm{fgh}}$ & $24.06 \pm 2.55^{\mathrm{gh}}$ & $28.9 \pm 3.07^{\mathrm{hi}}$ \\
\hline$J 4-1$ & $114.68 \pm 14.8^{d}$ & $59.61 \pm 7.69^{\text {de }}$ & $66.83 \pm 8.62^{e}$ \\
\hline$J 5$ & $61.98 \pm 5.8^{\text {efg }}$ & $29.48 \pm 2.76^{g h}$ & $42.59 \pm 3.99^{f g h i}$ \\
\hline Y2 & $129.24 \pm 16.12^{d}$ & $120.42 \pm 15.02^{\mathrm{a}}$ & $61.05 \pm 7.61^{\mathrm{ef}}$ \\
\hline YXM2 & $51.81 \pm 4.04^{\mathrm{fgh}}$ & $27.41 \pm 2.13^{g h}$ & $48.73 \pm 3.8^{\mathrm{efgh}}$ \\
\hline YD & $196.81 \pm 23.75^{b}$ & $82.42 \pm 9.95^{c}$ & $182.94 \pm 22.08^{b}$ \\
\hline $\mathrm{Y}_{1}$ & $221.99 \pm 20.28^{\mathrm{a}}$ & $94.89 \pm 8.67^{b}$ & $247.82 \pm 22.64^{\mathrm{a}}$ \\
\hline
\end{tabular}

free radicals and singlet oxygen [15, 24].GSW, 7403, DS, $\mathrm{Z1}, \mathrm{Z} 2, \mathrm{~T} 6, \mathrm{QM}$ and J4-1were the richest among the 23 cultivars in terms of bound phenolic compounds.

The data presented in Tables 6 and 7 show that the total phenol contents of Rut $(21.472 \mathrm{mg} / \mathrm{g} \mathrm{DW})$, Ast $(12.700 \mathrm{mg} / \mathrm{g} \mathrm{DW}), \mathrm{ChA}(245.249 \mathrm{mg} / \mathrm{g} \mathrm{DW})$, and $\mathrm{BeA}(0.055 \mathrm{mg} / \mathrm{g} \mathrm{DW})$ were generally consistent with those determined by Zou et al. [40], who reported a Rut content of $0.1-0.7 \mathrm{mg} / \mathrm{g} \mathrm{DW}$, an Ast content of 0.1$0.5 \mathrm{mg} / \mathrm{g}$ DW, a ChA content of $0.9-2.1 \mathrm{mg} / \mathrm{g}$ DW, and a BeA content of $0-0.2 \mathrm{mg} / \mathrm{g}$ DW.

Combined with Tables 6 and 7, only 10 phenolic compounds could be found in the bound phenolic content, which was one phenolic kindless than free phenol. Seven phenolic compounds were detected in both the free and bound fractions, indicating that they occur in mulberry leaves in both forms. Similar to the results for the free phenolic compounds, BeA was detected in the
Table 9 Antioxidant activities of the bound phenolic fractions of the 23 mulberry leaf samples

\begin{tabular}{|c|c|c|c|}
\hline Cultivar & $\begin{array}{l}\text { FRAP } \\
\left(\mu \mathrm{mol} \mathrm{Fe}^{2+} / \mathrm{g} \mathrm{DW}\right)\end{array}$ & $\begin{array}{l}\text { ABTS } \\
(\mu \mathrm{mol} \text { TEAC/g DW })\end{array}$ & $\begin{array}{l}\text { DPPH } \\
(\mu \mathrm{mol} \text { AEAC/g DW) }\end{array}$ \\
\hline G1 & $16.5 \pm 2.16^{\mathrm{ij}}$ & $9.34 \pm 1.22^{\text {fghi }}$ & $9.85 \pm 1.29^{\text {fghi }}$ \\
\hline G6 & $14.79 \pm 1.98^{\mathrm{ij}}$ & $6.52 \pm 0.88^{\mathrm{jk}}$ & $7.35 \pm 0.99^{\mathrm{jjk}}$ \\
\hline G8 & $14.52 \pm 2.37^{\mathrm{ij}}$ & $6.56 \pm 1.07^{\mathrm{jk}}$ & $7.23 \pm 1.18^{\mathrm{ijk}}$ \\
\hline GSW & $32.26 \pm 3.09^{c d}$ & $13.37 \pm 1.28^{c d}$ & $14.31 \pm 1.37^{\mathrm{de}}$ \\
\hline R2 & $22.71 \pm 2.71^{\mathrm{fgh}}$ & $9.55 \pm 1.14^{\mathrm{efgh}}$ & $8.77 \pm 1.05^{\text {hij }}$ \\
\hline 7403 & $13.52 \pm 2.04^{j}$ & $6.93 \pm 1.05^{\mathrm{ijk}}$ & $7.78 \pm 1.18^{\mathrm{ijk}}$ \\
\hline DS & $37.2 \pm 3.61^{b c}$ & $16.01 \pm 1.55^{a b}$ & $20.89 \pm 2.03^{b}$ \\
\hline B-2-8 & $39.15 \pm 5.06^{b c}$ & $15.31 \pm 1.98^{\mathrm{bc}}$ & $17.36 \pm 2.24^{c}$ \\
\hline $\mathrm{Z1}$ & $17.03 \pm 2.19^{\mathrm{hij}}$ & $8.94 \pm 1.15^{\text {ghij }}$ & $9.73 \pm 1.25^{g h i}$ \\
\hline $\mathrm{Z2}$ & $23.28 \pm 2.55^{\mathrm{fg}}$ & $11.81 \pm 1.29^{\text {def }}$ & $11.42 \pm 1.25^{\mathrm{efgh}}$ \\
\hline Z4 & $22.76 \pm 2.66^{\mathrm{fgh}}$ & $11.15 \pm 1.3^{\text {defg }}$ & $9.95 \pm 1.16^{\mathrm{fghi}}$ \\
\hline CGS & $29.45 \pm 2.57^{\mathrm{de}}$ & $12.38 \pm 1.08^{\mathrm{d}}$ & $15 \pm 1.31^{\mathrm{cd}}$ \\
\hline T6 & $41.89 \pm 5.11^{\mathrm{a} b}$ & $18.27 \pm 2.24^{\mathrm{a}}$ & $22.52 \pm 2.75^{a b}$ \\
\hline T7 & $12.74 \pm 1.44^{j}$ & $5.54 \pm 0.63^{k}$ & $5.11 \pm 0.58^{k}$ \\
\hline QM & $16.91 \pm 1.92^{\text {hij }}$ & $8.94 \pm 1.01^{\text {ghij }}$ & $10.02 \pm 1.14^{\mathrm{fghi}}$ \\
\hline BR60 & $26.21 \pm 2.76^{\mathrm{ef}}$ & $11.92 \pm 1.26^{\mathrm{de}}$ & $14.32 \pm 1.51^{\mathrm{de}}$ \\
\hline S54 & $13.65 \pm 1.53^{j}$ & $6.92 \pm 0.77^{\mathrm{jkk}}$ & $5.99 \pm 0.67^{\mathrm{jk}}$ \\
\hline$J 4-1$ & $28.47 \pm 3.04^{\mathrm{de}_{f}}$ & $13.31 \pm 1.42^{c d}$ & $12.72 \pm 1.36^{\text {def }}$ \\
\hline$J 5$ & $17.72 \pm 1.71^{g h i j}$ & $7.75 \pm 0.75^{\mathrm{hijk}}$ & $7.74 \pm 0.75^{i \mathrm{jk}}$ \\
\hline$Y_{2}$ & $45.93 \pm 4.83^{\mathrm{a}}$ & $14.99 \pm 1.58^{\mathrm{bc}}$ & $20.48 \pm 2.15^{b}$ \\
\hline YXM2 & $19.64 \pm 1.86^{\mathrm{ghi}}$ & $9.24 \pm 0.88^{g h i}$ & $11.93 \pm 1.13^{\mathrm{efg}}$ \\
\hline YD & $26.98 \pm 2.45^{\mathrm{def}}$ & $10.83 \pm 0.98^{\text {defg }}$ & $14.31 \pm 1.3^{\mathrm{de}}$ \\
\hline $\mathrm{Y}_{1}$ & $37.86 \pm 3.56^{b c}$ & $16.4 \pm 1.54^{\mathrm{ab}}$ & $24.05 \pm 2.26^{a}$ \\
\hline
\end{tabular}

bound fraction for samples G6, G8, and G1. Although the bound phenolic content was relatively low, it cannot be neglected, especially in the case of $\mathrm{CaA}$, because the conjugated forms have been demonstrated to act as more powerful antioxidants in various systems $[13,24]$.

\section{Antioxidant activity and its correlation with phenolic content}

The antioxidant activities of the free phenolic fractions of the 23 mulberry leaf samples were determined using three separate assays (FRAP, ABTS, and DPPH). As shown in Table 8, the FRAP, ABTS, and DPPH values ranged from $35.13 \mu \mathrm{mol} \mathrm{Fe}{ }^{2+} / \mathrm{g}$ DW (G1) to $227.8 \mu \mathrm{mol}$ $\mathrm{Fe}^{2+} / \mathrm{g}$ DW (CGS), from $19.81 \mu \mathrm{mol}$ TEAC/g DW (7403) to $120.42 \mu \mathrm{mol} \mathrm{TEAC/g} \mathrm{DW} \mathrm{(Y2),} \mathrm{and} \mathrm{from} 23.11 \mu \mathrm{mol}$ AEAC/g DW (G1) to $256.63 \mu \mathrm{mol} \mathrm{AEAC/g} \mathrm{DW} \mathrm{(CGS),}$ respectively. The free phenolic content and antioxidant activity exhibited a certain degree of positive correlation. 
Table 10 Correlation coefficients $\left(R^{2}\right)$ for the linear relationships between the total phenolic content, free phenolic content, bound phenolic content and FRAP, DPPH, and ABTS activities

\begin{tabular}{|c|c|c|c|c|c|c|c|c|c|}
\hline & FRAP $^{a}$ & $\mathrm{ABTS}^{\mathrm{b}}$ & $\mathrm{DPPH}^{\mathrm{c}}$ & FRAP $^{d}$ & ABTS & $\mathrm{DPPH}^{\mathrm{f}}$ & $P C_{\text {total }}{ }^{g}$ & $P C_{\text {free }}{ }^{h}$ & $P C_{\text {bound }}$ \\
\hline FRAP & 1 & 0.8898 & 0.96 & 0.6751 & 0.6437 & 0.7375 & 0.795 & 0.7973 & 0.1861 \\
\hline $\mathrm{ABTS}^{\mathrm{b}}$ & - & 1 & 0.7676 & 0.7876 & 0.6866 & 0.7878 & 0.7052 & 0.7059 & 0.2342 \\
\hline $\mathrm{DPPH}^{\mathrm{c}}$ & - & - & 1 & 0.5208 & 0.5338 & 0.6443 & 0.7722 & 0.7755 & 0.1234 \\
\hline FRAPd & - & - & - & 1 & 0.9532 & 0.9389 & 0.4926 & 0.4873 & 0.4582 \\
\hline $\mathrm{ABTS}^{\mathrm{e}}$ & - & - & - & - & 1 & 0.9495 & 0.4193 & 0.4131 & 0.4749 \\
\hline $\mathrm{DPPH}^{\mathrm{f}}$ & - & - & - & - & - & 1 & 0.4629 & 0.4606 & 0.2929 \\
\hline$P C_{\text {total }}{ }^{g}$ & - & - & - & - & - & - & 1 & 0.9998 & 0.3899 \\
\hline$P C_{\text {free }}{ }^{h}$ & - & - & - & - & - & - & - & 1 & 0.3732 \\
\hline$P C_{\text {bound }}{ }^{i}$ & - & - & - & - & - & - & - & - & 1 \\
\hline
\end{tabular}

${ }^{a}$ Ferric reducing antioxidant power of the free phenolic extract

b ABTS radical scavenging activity of the free phenolic extract

c DPPH radical scavenging activity of the free phenolic extract

d Ferric reducing antioxidant power of the bound phenolic extract

e ABTS radical scavenging activity of the bound phenolic extract

$f$ DPPH radical scavenging activity of the bound phenolic extract

$\mathrm{g}$ Total phenolic content

h Free phenolic content

i Bound phenolic content

As shown in Table 9, the FRAP values of the bound phenolic fractions of the 23 mulberry leaf samples ranged from $12.74 \mu \mathrm{mol} \mathrm{Fe}{ }^{2+} / \mathrm{g}$ DW (T7) to $45.93 \mu \mathrm{mol} \mathrm{Fe}{ }^{2+} / \mathrm{g}$ DW (Y2), which did not vary a lot probably. The ABTS values varied from $5.54 \mu \mathrm{mol} \mathrm{TEAC} / \mathrm{g} \mathrm{DW}$ (T7) to 18.27 $\mu \mathrm{mol}$ TEAC/g DW (T6), where T6 and T7 originated from the same country (Thailand). The DPPH values ranged from $5.11 \mu \mathrm{mol} \mathrm{AEAC/g} \mathrm{DW} \mathrm{(T7)} \mathrm{to}$ $24.05 \mu \mathrm{mol} \mathrm{AEAC/g} \mathrm{DW} \mathrm{(Y1).}$

Overall, the results of the three assays revealed a positive correlation between the free and bound phenolic contents and the antioxidant activities. Thus, the correlations between the antioxidant activities and the contents of individual phenolic compounds as determined by HPLC were evaluated to further examine the differences between the 23 cultivars.

\section{Correlation between antioxidant activities and contents of individual phenolic compounds}

Correlation analysis was conducted to determine whether any linear relationships existed between the antioxidant activities, total phenolic content, free phenolic content, bound phenolic content, and content of each phenolic component, and the results are summarized in Tables 10, 11 , and 12 . Owing to the diversity of the tested cultivars and differences in climate and other factors between different regions, the correlation of the different measured data was also different.
As shown in Table 10, between the phenolic contents and the antioxidant activities of the various extracts, the strongest correlation was observed between the free phenolic content and the FRAP values of the free phenolic extracts $\left(R^{2}=0.7978\right)$, followed by the relationship between the total phenolic content and the FRAP values of the free phenolic extracts $\left(R^{2}=0.795\right)$. The weakest correlation occurred between the bound phenolic content and the DPPH values of the free phenolic extracts $\left(R^{2}=0.1234\right)$. Previous studies have indicated that phenolic compounds greatly contribute to the antioxidant activity of mulberry leaves, especially the free phenolic content, which has the greatest influence. A strong correlation was also observed between the bound phenolic content about Rut and the ABTS values of the bound phenolic extracts $(\mathrm{R} 2=0.6797)$, indicating that certain phenolic compounds in the bound phenolic fraction may influence the removal of ABTS free radicals, such as CaA, Iso, and Que (Table 12). However, the correlation between total phenolic content and ABTS, free phenolic content and ABTS were the weakest, indicating that there may have been other substances present in the mulberry leaves that also affected the removal of ABTS free radicals, such as PrA (Table 11).

As shown in Tables 11 and 12, the contents of four phenolic compounds, namely, Iso, Rut, Sco, and ChA, exhibited positive correlations with the antioxidant activities of the free phenolic extracts as determined using all three assays, whereas the other seven phenolic 


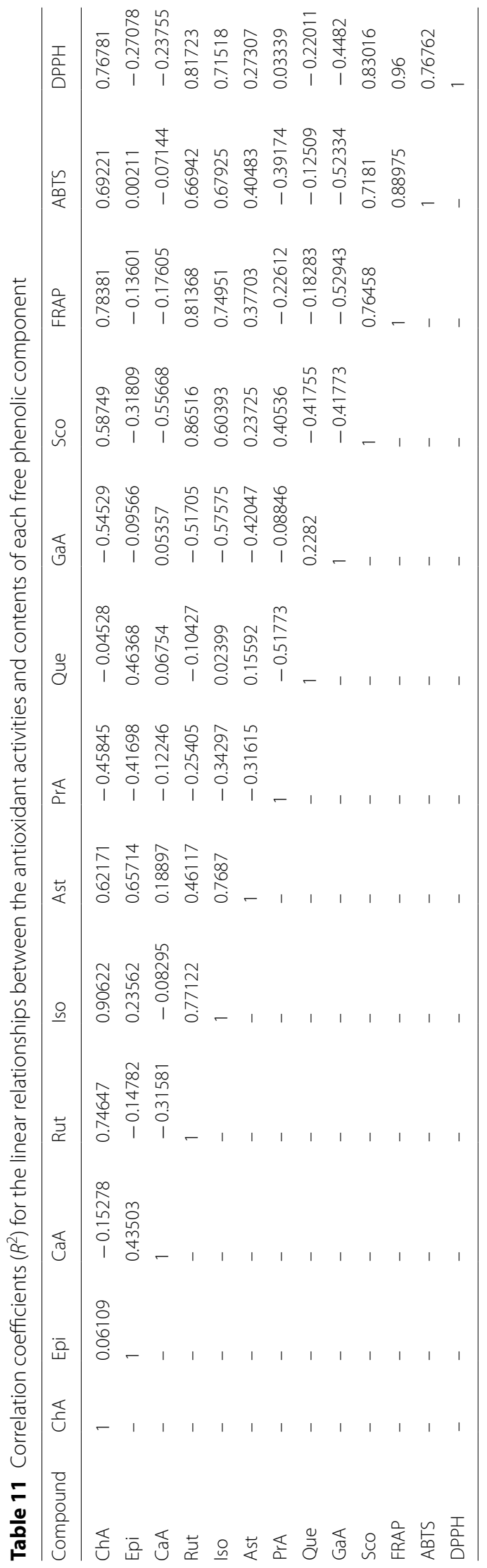




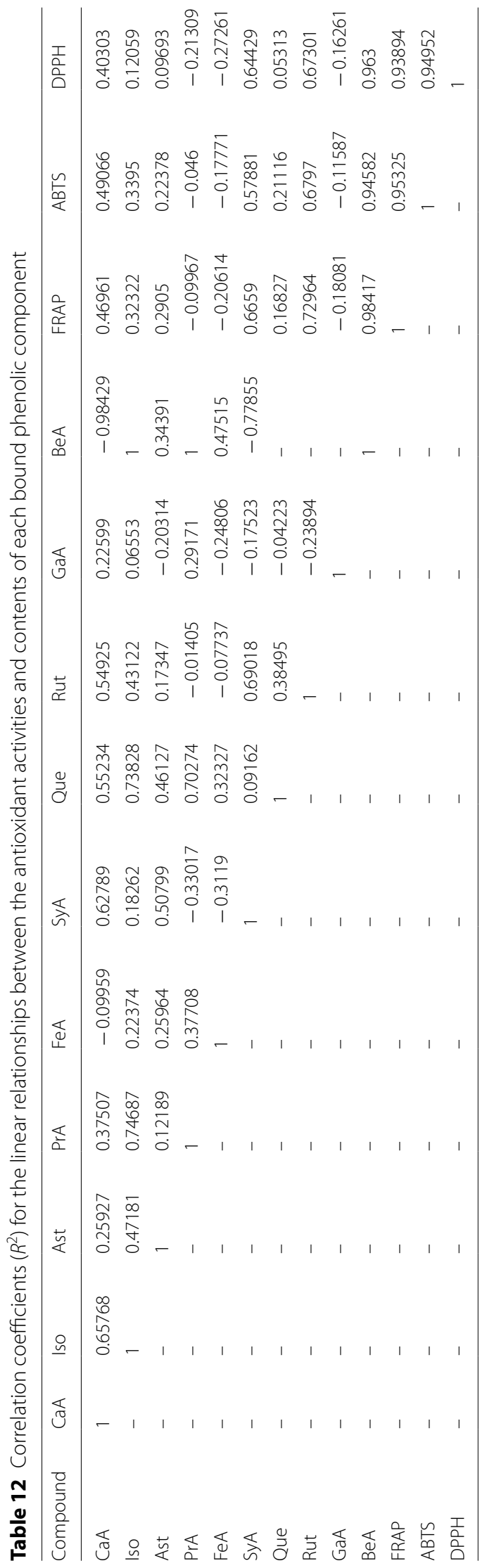


compounds displayed no obvious correlation with the antioxidant activities. The strength of these positive correlations followed the order Rut $>\mathrm{ChA}>\mathrm{Sco}>$ Iso for the FRAP activity, $\mathrm{Sco}>\mathrm{Rut}>\mathrm{ChA}>$ Iso for the DPPH activity, and $\mathrm{Sco}>\mathrm{ChA}>\mathrm{Iso}>$ Rut for the ABTS activity. However, as Sco was not detected in most of the samples, the free phenolic substances predominantly responsible for the antioxidant activities of the mulberry leaf samples appear to be Iso, ChA, and Rut. The correlation coefficient between the FRAP and DPPH assays was similar in Table 11, which indicates that these two assays were more suitable than the ABTS assay for measuring the antioxidant activity of free phenolic compounds. This may explain why the FRAP and DPPH assays have been more frequently applied to determine the phenolic antioxidant activity in previous studies [32, 39]. With respect to the bound phenolic compounds, SyA and Rut (Rut $>$ SyA) displayed a significant positive correlation with the antioxidant activities of the bound phenolic extracts as determined using all three assays, whereas no obvious correlation was observed for the other compounds.

Overall, the correlation between the phenolic contents and antioxidant activities fluctuated greatly, reflecting that phenolic compounds are the main antioxidants in mulberry leaves.

\section{Conclusions}

The phenolic compositions and antioxidant activities of leaves from 23 mulberry varieties cultivated in several countries and regions were characterized using LCESI-QTOF and three separate antioxidant assays (FRAP, ABTS, and DPPH). The results revealed significant differences in the phytochemical contents and antioxidant activities between the samples. The phenolic compounds in mulberry leaves predominantly existed in the free form. CGS from Taiwan displayed the highest phenolic content as well as superior antioxidant activity compared with the other 22 cultivars, as determined by the FRAP, ABTS, and DPPH assays. Furthermore, the obtained results demonstrated that $\mathrm{ChA}$ and $\mathrm{CaA}$ were the main phenolic compounds in the free and bound fractions, respectively. Iso, ChA, and Rut accounted for the majority of the antioxidant activity in the free phenolic fractions, while SyA and Rut were positively correlated with the antioxidant activity of the bound phenolic fractions. Taken together, these results indicate that the antioxidant activity of mulberry leaves is related to the content and types of phenolic compounds present.

\section{Abbreviations}

Rut: Rutin; Que: Quercetin; Quer: Quercitrin; Iso: Isoquercitrin; ChA: Chlorogenic acid; SyA: Syringic acid; FeA: Ferulic acid; CaA: Caffeic acid; Res: Resveratrol; Epi: Epicatechin; Ast: Astragalin; Sco: Scopoletin; Gal: Galangal;
CatA: Catechuic acid; VaA: Vanillic acid; BeA: Benzoic acid; GaA: Gallic acid; PrA: Protocatechuic acid; TPTZ: 2,4,6-Tris(2-pyridyl)-S-triazine; DPPH: 1,1-Diphenyl2-picrylhydrazyl; ABTS: 2,2'-Azino-bis(3-ethylbenzothiazoline-6-sulfonic acid) diammonium salt; trolox: 6-Hydroxy-2,5,7,8-tetramethylchroman-2-carboxylic acid; FRAP: Ferric reducing antioxidant power; AEAC: Ascorbic acid equivalent antioxidant capacity; TEAC: Trolox equivalent antioxidant capacity; RT: Retention time.

\section{Acknowledgements \\ Not applicable.}

\section{Authors' contributions}

Conception and design of study, Acquisition of data laboratory or clinical, Analysis of data, Drafting of article and/or critical revision, WZJ; Acquisition of data laboratory or clinical, Drafting of article and/or critical revision, TCM; Conception and design of study, Analysis of data, XGS; Acquisition of data laboratory or clinical, Drafting of article and/or critical revision, DFW; Conception and design of study, Drafting of article and/or critical revision, LS; Acquisition of data laboratory or clinical, Final approval of manuscript, LZY; Analysis of data, Final approval of manuscript, LGQ.

\section{Funding}

This work was supported by the Key-Area Research and Development Program of Guangdong Province (2020B020225005), National Key R\&D Program of China(2019YFD1001200), China agriculture research system (No. CARS-18SYZ13), the Modern agricultural industry technology system innovation team of Guangdong Province (2019KJ124).

Availability of data and materials

The datasets generated during and/or analysed during the current study are available from the corresponding author on reasonable request.

\section{Declarations}

Ethics approval and consent to participate

Not applicable.

Consent for publication

Not applicable.

\section{Competing interests}

The authors declare that they have no competing interests.

\section{Author details}

${ }^{1}$ Sericulture \& Agri-Food Research Institute, Guangdong Academy of Agricultural Sciences, Guangzhou, China. ${ }^{2}$ Key Laboratory of Urban Agriculture in South China, Ministry of Agriculture and Rural Affairs, Guangzhou, China.

Received: 22 October 2020 Accepted: 17 March 2021

Published online: 29 March 2021

\section{References}

1. Ahmed AF, Attia FAK, Liu Z, Li C, Kang W (2019) Antioxidant activity and total phenolic content of essential oils and extracts of sweet basil (Ocimum basilicum L.) plants. Food Sci Hum Wellness 8:299-305

2. Anwar F, Kanwal S, Shabir G, Alkharfy KM, Gilani AH (2015) Antioxidant and antimicrobial attributes of different solvent extracts from leaves of four species of mulberry. Int J Pharmacol 11:757-765

3. Arabshahi-Delouee S, Urooj A (2007) Antioxidant properties of various solvent extracts of mulberry (Morus indica L.) leaves. Food Chem. 102:1233-1240

4. Baranwal VK, Negi N, Khurana P (2017) Auxin response factor genes repertoire in mulberry: identification, and structural, functional and evolutionary analyses. Genes 8:202

5. Begum A, Goswami A, Chowdhury P (2015) A comparative study on free and bound phenolic acid content and their antioxidant activity in bran of rice (Oryza sativa L.) cultivars of Eastern Himalayan range. Int J Food Sci Technol 50:2529-2536 
6. Bose PC (1989) Genetic Resources of Mulberry and Utilization. Central Sericulture Research and Training Institute, Mysore, pp 183-190

7. Cai Y, Luo Q, Sun M, Corke H (2004) Antioxidant activity and phenolic compounds of 112 traditional Chinese medicinal plants associated with anticancer. Life Sci 74:2157-2184

8. Cetkovic GS, Canadanovic-Brunet JM, Djilas SM, Tumbas VT, Markov SL, Cvetkovic DD (2007) Antioxidant potential, lipid peroxidation inhibition and antimicrobial activities of Satureja montana L. subsp. kitaibelii extracts. Int J Mol Sci 8:1013-1027

9. Doi K, Kojima T, Makino M, Kimura Y, Fujimoto Y (2001) Studies on the constituents of the leaves of Morus alba L. Chem Pharm Bull 49:151-153

10. Eom JH, Vu TPD, Cai L, Zhao Y, Li H, Yang SY, Kim YH, Kim SJ, Cho HS, Bao H, Chem J, Kim TK, Kang JS (2017) Development of HPLC method for differentiation of three parts of mulberry tree. Anal Sci Technol 30:130-137

11. Ercisli S, Tosun M, Duralija B, Voca S, Sengul M, Turan M (2010) Phytochemical content of some black (Morus nigra L.) and purple (Morus rubra L.) mulberry genotypes. Food Technol Biotechnol. 48:102-106

12. Fan G, Beta T (2017) Discrimination of geographical origin of Napirira bean (Phaseolus vulgaris L.) based on phenolic profiles and antioxidant activity. J Food Compos Anal 62:217-222

13. Fukumoto LR, Mazza G (2000) Assessing antioxidant and prooxidant activities of phenolic compounds. J Agric Food Chem 48:3597-3604

14. Gundogdu M, Muradoglu F, Gazioglu RI, Yilmaz H (2011) Determination of fruit chemical properties of Morus nigra L., Morus alba L. and Morus rubra L. by HPLC. Sci Hortic 132:37-41

15. Kikuzaki H, Hisamoto M, Hirose K, Akiyama K, Taniguchi H (2002) Antioxidant properties of ferulic acid and its related compounds. J Agric Food Chem 50:2161-2168

16. Kim J-M, Chang S-M, Kim I-H, Kim Y-E, Hwang J-H, Kim K-S, Kim W-S (2007) Design of optimal solvent for extraction of bio-active ingredients from mulberry leaves. Biochem Eng J 37:271-278

17. Kono Y, Shibata H, Kodama Y, Sawa Y (1995) The suppression of the $\mathrm{N}$-nitrosating reaction by chlorogenic acid. Biochem J 312:947-953

18. Krygier K, Sosulski F, Hogge L (1982) Free, esterified, and insoluble-bound phenolic acids. 1. Extraction and purification procedure. J Agric Food Chem 30:330-334

19. Laranjinha JA, Almeida LM, Madeira VM (1994) Reactivity of dietary phenolic acids with peroxyl radicals: antioxidant activity upon low density lipoprotein peroxidation. Biochem Pharmacol 48:487-494

20. Li Y, Liu M, Wan H, Sun H, Cong Y, Xu B, Liu D (2015) Determination of free and bound phenol of corn by high performance liquid chromatography (HPLC). J Chin Cereals Oils Assoc 30:108-111

21. Madhujith T, Shahidi F (2009) Antioxidant potential of barley as affected by alkaline hydrolysis and release of insoluble-bound phenolics. Food Chem 117:615-620

22. Materska M (2015) Flavone C-glycosides from Capsicum annuum L: relationships between antioxidant activity and lipophilicity. Eur Food Res Technol 240:549-557

23. Memon AA, Memon N, Luthria DL, Bhanger MI, Pitafi AA (2010) Phenolic acids profiling and antioxidant potential of mulberry (Morus laevigata W., Morus nigra L., Morus alba L.) leaves and fruits grown in Pakistan. Pol J Food Nutr Sci 60:25-32

24. Meyer AS, Donovan JL, Pearson DA, Waterhouse AL, Frankel EN (1998) Fruit hydroxycinnamic acids inhibit human low-density lipoprotein oxidation in vitro. J Agric Food Chem 46:1783-1787
25. Onogi A, Osawa K, Yasuda H, Sakai A, Morita H, Itokawa H (1993) Flavonol glycosides from the leaves of Morus alba L. Nat Med 47:423-425

26. Qadir R, Anwar F, Gilani MA, Zahoor S, ur Rehman MM, Mustaqeem M (2019) RSM/ANN based optimized recovery of phenolics from mulberry leaves by enzyme-assisted extraction. Czech J Food Sci 37:99-105

27. Re R, Pellegrini N, Proteggente A, Pannala A, Yang M, Rice-Evans C (1999) Antioxidant activity applying an improved ABTS radical cation decolorization assay. Free Radicals Biol Med 26:1231-1237

28. Rice-Evans CA, Miller NJ, Paganga G (1996) Structure-antioxidant activity relationships of flavonoids and phenolic acids. Free Radicals Biol Med 20:933-956

29. Saleem A, Ahotupa M, Pihlaja K (2001) Total phenolics concentration and antioxidant potential of extracts of medicinal plants of Pakistan. Z Naturforsch C 56:973-978

30. Sánchez-Salcedo EM, Mena P, García-Viguera C, Hernández F, Martínez JJ (2015) (Poly)phenolic compounds and antioxidant activity of white (Morus alba) and black (Morus nigra) mulberry leaves: their potential for new products rich in phytochemicals. J Funct Foods 18:1039-1046

31. Santas J, Carbó R, Gordon MH, Almajano MP (2008) Comparison of the antioxidant activity of two Spanish onion varieties. Food Chem 107:1210-1216

32. Siddhuraju P (2007) Antioxidant activity of polyphenolic compounds extracted from defatted raw and dry heated Tamarindus indica seed coat, LWT-Food Sci. Technol 40:982-990

33. Subhashinee SKW, Mamdouh MA, Fereidoon S (2006) Antioxidant polyphenols in almond and its coproducts. J Agric Food Chem 13:659-672

34. Sumczynski D, Bubelova Z, Sneyd J, Erb-Weber S, Mlcek J (2015) Total phenolics, flavonoids, antioxidant activity, crude fibre and digestibility in non-traditional wheat flakes and muesli. Food Chem 174:319-325

35. Thabti I, Marzougui N, Elfalleh W, Ferchichi A (2011) Antioxidant composition and antioxidant activity of white (Morus alba L.), black (Morus nigra L.) and red (Morus rubra L.) mulberry leaves. Acta Bot Gallica 158:205-214

36. Tomas M, Toydemir G, Boyacioglu D, Hall R, Beekwilder J, Capanoglu E (2015) The effects of juice processing on black mulberry antioxidants. Food Chem 186:277-284

37. Velioglu YS, Mazza G, Gao L, Oomah BD (1998) Antioxidant activity and total phenolics in selected fruits, vegetables, and green products. J Agric Food Chem 46:4113-4117

38. Wu C-H, Chen S-C, Ou T-T, Chyau C-C, Chang Y-C, Wang C-J (2013) Mulberry leaf polyphenol extracts reduced hepatic lipid accumulation involving regulation of adenosine monophosphate activated protein kinase and lipogenic enzymes. J Funct Foods 5:1620-1632

39. Zhang R, Huang L, Deng Y, Chi J, Zhang Y, Wei Z, Zhang M (2017) Phenolic content and antioxidant activity of eight representative sweet corn varieties grown in South China. Int J Food Prop 20:3043-3055

40. Zou Y, Liao S, Shen W, Liu F, Tang C, Chen C-YO, Sun Y (2012) Phenolics and antioxidant activity of mulberry leaves depend on cultivar and harvest month in Southern China. Int J Mol Sci 13:16544-16553

\section{Publisher's Note}

Springer Nature remains neutral with regard to jurisdictional claims in published maps and institutional affiliations. 